\title{
Summary proceedings
}

\author{
WORKSHOP ON REDD+ AND LEGAL REGIMES OF \\ MANGROVES, PEATLANDS AND OTHER WETLANDS: \\ ASEAN AND THE WORLD
}

15-16 November 2012

Asia-Pacific Centre for Environmental Law (APCEL), Faculty of Law, National University of Singapore

WORKSHOP ON REDD+ AND LEGAL REGIMES OF MANGROVES, PEATLANDS AND OTHER WETLANDS: ASEAN AND THE WORLD 


\section{WORKSHOP REPORT}

HOSTED BY

Asia-Pacific Centre for Environmental LaW (APCEL)

FACULTY OF LAW

NATIONAL UNIVERSITY OF SingAPORE

SUPPORTED BY

National Climate Change Secretariat (NCCS)

PRIME MiNISTER'S OFFICE

SINGAPORE

Rapporteur:

Lovleen BHULLAR

Edited by:

Lovleen BHULLAR

KOH Kheng Lian

LYE Lin-Heng

15-16 November 2012

Singapore

ASIA-PACIFIC CENTRE FOR ENVIRONMENTAL LAW (APCEL), FACULTY OF LAW, NATIONAL UNIVERSITY OF SINGAPORE 


\section{CONTENTS PAGE}

OPENING SESSION AND OVERVIEW ………....................................................................... 4

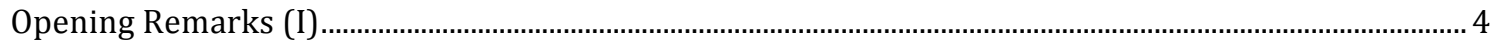

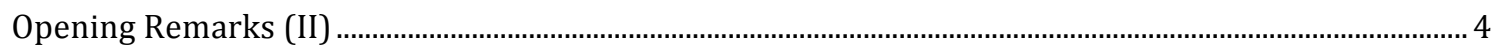

Theme I: Setting the Stage: Overview of General Issues Relating to REDD+: ASEAN and

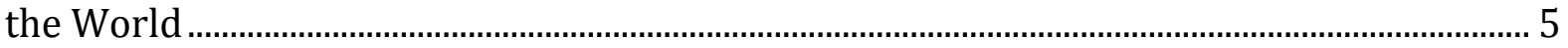

Theme II: Scientific, Economic and Policy Considerations ........................................................ 6

Tropical Wetlands and REDD+: Unique Scientific Challenges for Policy …………..................................... 6

The Economics of Mangrove Biodiversity and Ecosystem Services in Relation to Climate Change ...... 7

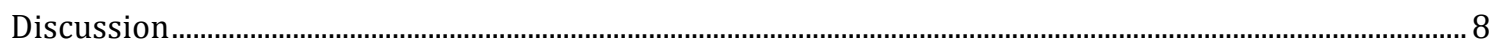

Theme III: ASEAN and the World: Mangroves, Peatlands and Other Wetlands ................... 8

Mangroves, Peatlands and Other Wetlands: Global Cooperation among National Programmes............ 8

A Survey of ASEAN Instruments on Peatlands, Mangroves and Other Wetlands: The REDD+ Context?

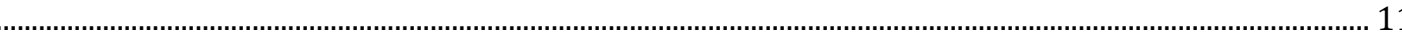

Peatlands and Climate Change: the ASEAN GEF-IFAD Peatland Project..................................................... 12

Implementing REDD+ through a Private Sector Partnership in Kalimantan, Indonesian Borneo ...... 13

Exploiting the Wetlands in the Anthropocene Epoch: The Structure and Development of the

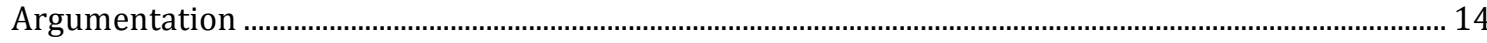

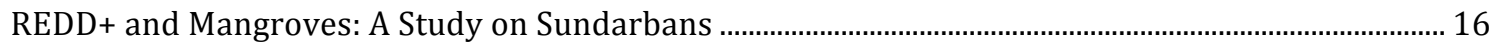

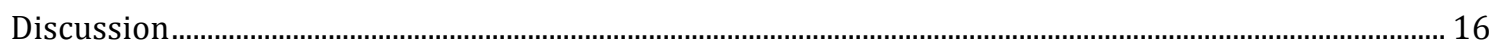

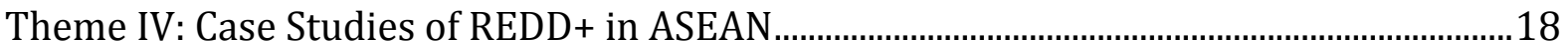

The Progress on REDD+ Institutionalization in Indonesia ........................................................................... 18

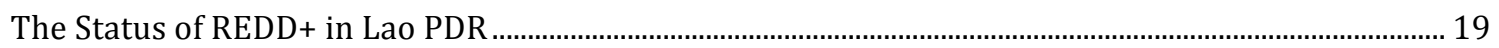

REDD+ in Philippines: Legal Status and Conservation of Mangrove Forests in the Philippines .......... 21

Asian Development Bank's REDD+ Related Work in the Greater Mekong Subregion .............................. 23

The Trials and Tribulations of Developing REDD+ Legislation in Indonesia............................................. 24

Extending REDD+ to Mangroves and Wetlands for Small Island States \& Conservation of Mangroves

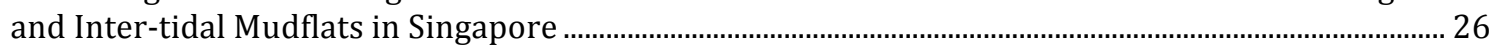

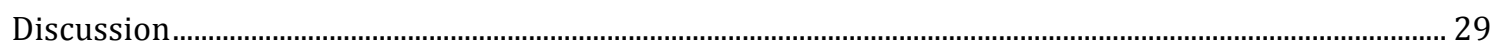

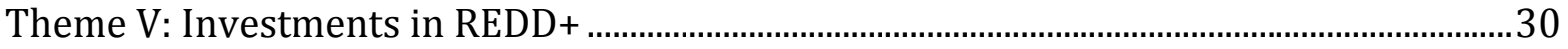

REDD+ and the Current State of the Market: A Role for Singapore? ………………................................... 30

REDD+ and CDM: A Comparative Perspective..................................................................................................... 32

REDD+ Investments: The Experience of Carbon Conservation ..................................................................... 33

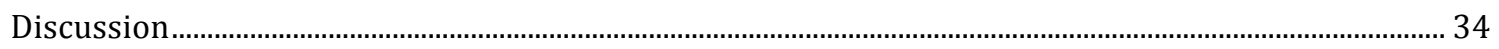

Theme VI: Tackling REDD+ Issues and Drafting Legal Framework ……..................................35

Law and Policy on Peatlands: The Indonesian Experience........................................................................ 35

Managing Risks of Using REDD+ to Manage Rich Socio-ecological Systems ................................................ 37

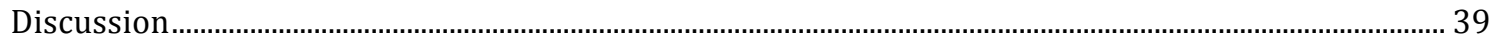

Fostering REDD+ Investment through Effective Legal Frameworks: Lessons from the Development

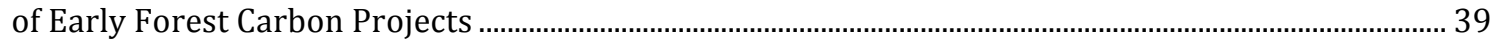

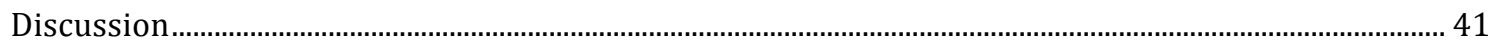

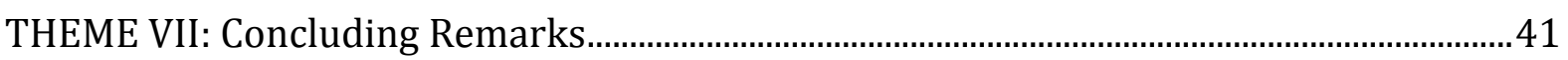

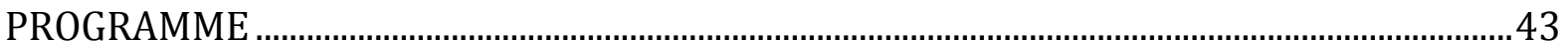

INVITED GUESTS 
This report summarises the proceedings of the workshop as interpreted by the assigned rapporteur and editors of the Asia-Pacific Centre for Environmental Law, which were reviewed and approved by the presenters.

\section{OPENING SESSION AND OVERVIEW}

A workshop on REDD+ and Legal Regimes of Mangroves, Peatlands and other Wetlands: ASEAN and the World was held in Singapore on 15-16 November 2012. The workshop was organised by the Asia-Pacific Centre for Environmental Law, Faculty of Law, National University of Singapore and supported by the National Climate Change Secretariat (NCCS) of the Prime Minister's Office, Singapore. The workshop proceedings took place in Seminar Room 2-1, Level 2, Block B, Faculty of Law, Bukit Timah Campus, National University of Singapore. Emeritus Professor Koh Kheng Lian, Director, AsiaPacific Centre for Environmental Law began the day's proceedings by introducing the distinguished guests during the opening session of the workshop.

\section{Opening Remarks (I)}

\section{Prof Simon Chesterman}

Dean, Faculty of Law, National University of Singapore

In his opening remarks, Prof Chesterman welcomed everyone to the workshop. He quoted the definition of REDD+ and highlighted the importance of developing an appropriate regulatory regime. He drew the attention of the participants to the fact that Southeast Asia is home to several million hectares of mangroves, peatlands and other wetlands. There is an urgent need to develop national legislation that addresses the issues of conservation, restoration and adaptation.

\section{Opening Remarks (II)}

\section{Ms Evelyn Khoo}

Director (Policy \& Planning), National Climate Change Secretariat, Singapore

Ms Khoo emphasised the need for a robust REDD+ mechanism and drew attention to the multi-level processes at the international, regional, bilateral, national and local level. She then introduced the participants to the National Climate Change Secretariat (NCCS), which was set up in 2010 in the Prime Minister's Office and reports to the Deputy Prime Minister. NCCS works closely with agencies such as the Ministry of Trade and Industry and the Ministry of Environment and Water Resources in the development of plans and policies related to climate change. The National Climate Change Strategy document was released in June 2012 and it articulates Singapore's strategy related to climate change mitigation, adaptation, green growth and partnerships. Ms Khoo identified the following aims of the workshop:

- To identify gaps and needs in legal frameworks relating to mangroves, peatlands and other wetlands

- To promote understanding and implementation of effective legal frameworks and REDD+ for mangroves, peatlands and other wetlands

According to her, NCCS is interested in the workshop from a policy practitioner's point of view. 


\section{Theme I: Setting the Stage: Overview of General Issues Relating to REDD+: ASEAN and the World}

The introductory panel comprised Prof Nicholas A Robinson, Mr Ralph Strebel, Ms Tiina Korvela, Dr Dan Friess, Dr Laode M Syarif and Prof Paul Martin.

Prof Nicholas Robinson highlighted the problems of protecting forests of which wetlands are a subset. Initially, wetlands were destroyed through development activities because their value was not recognised. The science of ecology emerged as a discipline post World War II. Advances in the use of satellites and data collection have improved global remote sensing capacity. However, the loss of wetlands continues unabated. He emphasised the importance of developing tools that value and enhance wetlands and lead to the creation of more wetlands.

Regarding the inland migration of marine wetlands as a response to sea level rise, he referred to the recent hurricanes in New York and said that REDD+ is a possible solution to the existing crisis and it will form a part of the new climate treaty that results from the ongoing climate negotiations. There is a need to fast track REDD+ implementation.

Mr Ralph Strebel stated that REDD+ projects are ongoing in Australia, South East Asia and Africa. But an on-the-ground legal perspective identifies a number of gaps and challenges, and highlights the need to create a foundation/ structure or a policy base. From a technical perspective, it is necessary to get REDD+ projects off the ground. There are two REDD+ projects in South East Asia but no credits have been produced. He identified financial hurdles as obstacles to a market for REDD+ projects. There are more Official Development Assistance (ODA) funds for REDD+ but they are on the capacity building side. There is a need to create a market signal, inter alia, by strengthening the legal structure. This would allow legalisation of REDD+ projects within forestry, agriculture codes and allow states/ entities to hold REDD+ credits.

Ms Tiina Korvela provided an introduction to inland wetlands in Finland, which are used for forestry, agriculture and energy production (through excavation of peat, which is harmful for the environment). Climate change is not addressed in the National Strategy for Mines and Peatlands 2011. The reason is the history and culture of Finland. However, courts and regional authorities have made innovative rulings regarding wetlands.

Dr Dan Friess introduced the audience to the differences between tropical wetlands, mangroves and peat swamps, and their role in carbon sequestration.

Dr Laode M Syarif informed the audience that Indonesia is the third largest tropical forest in the world but has the highest deforestation rate. It is also home to 50 per cent of the world's peatlands. He mentioned a cooperative arrangement between the Government of Norway and the Government of Indonesia based on a Letter of Intent, which will be discussed in greater detail later.

Prof Paul Martin highlighted the human challenge to make REDD+ work. REDD+ involves use of a carbon commodity product to protect non-carbon values, with an intrinsic potential conflict between priced and un-priced interests. A robust institutional structure is necessary, but not easy to achieve. Unfortunately, instruments rather than institutions have formed the focus of the design of carbon markets. It is 
necessary to ask whether the institutions and the instruments working together can do what we want them to do and how. How do we align incentives, when some values are directly priced but others are not? How do we build or strengthen the capacity of disadvantaged people, ensuring that their social values are not compromised in the pursuit of 'marketised' carbon values? How do we ensure that these social values are dealt with in ways that are economically efficient for the carbon market? Given the high potential for some of the key ambitions of REDD+ to conflict, the issue of risk is significant suggesting the need for a governance framework, which incorporates strategic risk management.

\section{Theme II: Scientific, Economic and Policy Considerations}

\section{Moderator: Ms Lovleen Bhullar}

\section{Tropical Wetlands and REDD+: Unique Scientific Challenges for Policy}

\section{Dr Dan Friess}

Assistant Professor, Department of Geography, National University of Singapore

Dr Friess began his presentation by describing the important role of tropical wetlands (primarily mangroves and peat swamp forests) in carbon sequestration and storage. The growing interest to incorporate tropical wetlands into REDD+ is on account of the fact that their loss through deforestation has disproportionate impacts on carbon dioxide levels in the atmosphere relative to their total land area. He said it is more difficult to incorporate tropical wetlands into REDD+ than terrestrial forests. He then discussed four issues concerning tropical wetlands to explain this statement. Serious research on how to fill gaps and create capacity has only been undertaken recently.

First, the management of tropical wetlands that are inherently ephemeral and dynamic ecosystems is difficult especially where externalities affect these dynamics. For example, mangroves can only tolerate a certain level of flooding (rise and fall) annually. Sea level rise is the biggest externality, which is very difficult to control. In this context, he raised questions about the adequacy of current/ proposed legal boundaries of a Payment for Ecosystem Services (PES) scheme based on terrestrial ecosystems for effective protection of a wetland that is subject to a diverse range of external stressors, legal responsibility in case of failure of a REDD+ scheme due to external/ transboundary stressors, policies for holistic management of a wetland landscape and existing/ planned platforms for successful transboundary management.

Second, adjusting carbon dynamics in tropical wetlands, which operate on timescales that are not directly transferable to REDD+ policy-relevant timescales, is a major issue. Old stable mangroves have high biomass (storage) but low productivity (accumulation) while restored mangroves have low biomass but high productivity. But the latter may not be enough over a REDD+ timescale. Further, it is difficult to measure long-term carbon fluxes. He also highlighted the issue of permanence, i.e. what happens after the REDD+ project. This raises questions about the most appropriate forest age for protection and the mechanisms to protect carbon stocks and accumulation over time scales that are longer than PES schemes.

Third, while it is relatively easier to map carbon in trees (at the national, regional or global scale) based on ground measurements and remote sensing, most carbon in 
tropical wetlands is stored below ground in soil and peat and the soil store is not uniform. As a result, while point measurements are technically feasible, it is not sufficient for accurate Monitoring, Reporting and Verification (MRV) of below ground total carbon stocks as it is not representative of the entire mangrove. The level of inaccuracy/ estimation that decision makers and investors are willing to accept represents a major challenge.

Fourth, tropical wetlands are largely understudied compared to terrestrial forests and there are greater knowledge gaps. For example, the determination of national estimates (based on historical baselines or other methodologies) that are transparent, consistent and accurate and reduce uncertainties is an issue for developing and developed countries. There are uncertainties in data impacts, e.g. a REDD investor would want to show a bad deforestation rate. Accurate baseline data is essential to quantify "avoided deforestation". Dr Friess identified a number of issues for policy makers relating, inter alia, to filling this knowledge gap, the level of uncertainty that decision makers and investors are willing to tolerate, how to prevent cherry-picking of information and capacity building (including availability of funds and transfer of capacity between countries).

\section{The Economics of Mangrove Biodiversity and Ecosystem Services in Relation to Climate Change}

Dr Filliberto A Pollisco

Policy and Program Development Specialist, ASEAN Centre for Biodiversity, Los Banos, Laguna, Philippines

South East Asia is home to 70 per cent of the total species of mangroves, and the IndoMalayan Philippine Archipelago has 36 to 47 of 70 known mangrove species. Mangroves have a slow decomposition rate and they can store more carbon than rainforests.

The region also has the highest rate of mangrove loss in the world, losing $629 \mathrm{~km} 2$ per year in two decades. Pond culture converted from mangrove intertidal areas is responsible for 50-80 per cent of this loss. Vast areas of mangroves have also been cleared due to coastal development, aquaculture, population encroachment and fuel wood and timber production. Three mangrove species, which are categorised as "critically endangered" in the IUCN Red List of Endangered Species, are of special concern in the ASEAN region.

Mangroves function as a huge carbon store, they develop very fast because the root biomass is almost half of the total plant biomass and they are the first line of defence against sea level rise. However, climate change affects mangrove ecosystems at three levels - tissue/ cellular level, ecosystem-wide level and region-wide level.

The REDD+ mechanism focuses on the carbon stock of the mangrove ecosystem. Valuation plays an important role in measuring the mangrove ecosystem services and its biodiversity, and in decision-making and planning for mangrove development. Usually, only above-ground biomass is measured for REDD purposes. This undervalues the carbon stock of the mangrove ecosystem. However, for the market, it is better to have lower estimates of carbon than higher estimates. 
In 2012, the ASEAN Centre for Biodiversity published a The Economics of Ecosystems and Biodiversity (TEEB) Scoping Study, which assessed and valued key ecosystems in Southeast Asia (including mangrove ecosystems) and their services, in order to assist ASEAN Member States to develop green growth economies. The study estimates foregone annual benefits by 2050 for the ASEAN region to be USD 2.2 billion. The study found that the value of individual mangroves is enhanced in the presence of other large patches in surrounding areas. Therefore, preservation of contiguous areas is preferable to widely dispersed patches. Mangrove conservation efforts should also aim to mitigate impacts of fragmentation by road infrastructure.

In the future, there is a need for collaborative research that combines ecology and economics. It is also necessary to include spatially defined variables to account for variations in values of ecosystem services. Specific threats should be modelled to estimate changes in stocks of mangroves over time to improve the estimated values. Finally, value transfer analysis should be revisited when data on services from mangroves becomes available.

\section{Discussion}

It is difficult to enact a law on Payment for Ecosystem Services because the value of ecosystem services varies with supply and demand, etc. According to one participant, the legal system is not appropriate for valuation. It is also difficult to legislate because ecosystem services are site-specific. For example, although Vietnam does not have such a law, it has a policy on payment for ecosystem services.

\section{Theme III: ASEAN and the World: Mangroves, Peatlands and Other Wetlands}

\section{Moderator: Assoc Prof Lin-Heng Lye}

\section{Mangroves, Peatlands and Other Wetlands: Global Cooperation among National Programmes}

\section{Prof Nicholas A Robinson \\ Gilbert \& Sarah Kerlin Distinguished Professor of Environmental Law \& Co-Director, Center for Environment Legal Studies, Pace University School of Law, New York}

Wetlands are in jeopardy all over the world. The awareness of the importance of conserving wetlands of all types has emerged slowly. The Ramsar Convention on Wetlands of International Importance especially as Waterfowl Habitat provides the international context in which wetlands are regarded. Its objective is to protect large wetlands for migratory avian species and to stabilise their habitats. States were invited to voluntarily designate large wetland areas. Over time, the Ramsar approach has expanded from large wetlands into an ecosystem management approach.

But ultimately, effective wetlands stewardship is essentially the responsibility of each nation through its national environmental laws. The Ramsar Convention contemplates that each nation should adopt its own wetlands legislation in order to promote the "wise use of wetlands in their territory". The several Ramsar Handbooks for the Wise Use of Wetlands include Handbook 3 on "Laws and Institutions", which provide 
guidance for how nations may assess and advance their wetlands laws. However, this and other guidance have not been followed by many nations and the enactment of national legislation is not being pursued in a meaningful way. As an exception, Prof Robinson gave the example of New York, which enacted a Tidal Wetlands Act of 1969 to save the remaining saltwater wetlands along New York's marine coastlines from being filled and destroyed. This was followed by the Freshwater Wetlands Act to provide stewardship for freshwater or inland wetlands.

In addition to the traditional reasons for protecting wetlands through legislation, the priority assigned to enacting wetland laws can be enhanced if they are regarded as a climate change priority. As a result, wetlands can become a potential recipient of climate change-related funding from intergovernmental multilateral sources and/ or their ecosystem services may be monetised and paid for by the beneficiaries (also known as payment for ecosystem services or PES).

He gave the example of the system of payments that New York City makes annually to the towns and property owners to protect the watershed of the Catskill Mountains where the City's remote drinking water reservoirs are situated instead of making significant investments into new water filtration systems. Another proposal aims to create an economic market for wetlands through the mechanism known as REDD+.

However, neither PES nor REDD+ are widely in use as ways to promote stewardship of wetlands. Instead, the largest body of experience for wetlands laws is through national environmental law. According to Prof Robinson, an efficient national wetlands law may qualify a nation's wetlands for payments for ecosystem services or for REDD+ payments internationally through national laws that can meet verified carbon standards internationally.

He observed that one consistent version of a wetland/ peatland/ mangrove is absent in law. Because wetlands are found in different contexts - they serve different functions and they can be conceived of in different ways, they are regulated under different laws. For example, they may be regulated as forests (e.g. in the case of mangroves), under soil conservation regimes, as a "mined" resource (such as peat for fuel in Finland), as wildlife habitat, or as watersheds etc. According to him, such an approach is unscientific and counter-productive and it fails to create long-term resilience/ integrity of the system.

He then contrasted two case studies of wetlands laws in the United States - the successful regime in New York State and the conflicted and marginally successful federal regime.

The New York Freshwater Wetlands Act establishes the scientific and other values of wetlands, which make the public policy case for the enactment of legislation explicitly focused on wetlands. The law gave clear notice to the public as to where wetlands exist and the values for which they were protected. Farmers were given leeway to farm on areas where wetlands may exist by exempting relatively small wetlands but local authorities were authorised to designate any of these small areas if significant conservation values were in danger because of their potential loss. Public participation was ensured at every step with ample notice and opportunities to be heard. People were educated about the law. In order to ensure access to justice, inexpensive administrative appeals, as well as judicial review, were provided. Transparency was ensured and the permit system was administered efficiently and without corruption. 
There was a marked decline in disputes about wetlands because wetlands were delineated carefully and mapped.

On the other hand, the US Federal law rests on a flawed concept and definition of wetlands. Wetlands are deemed to be part of the 'waters of the United States' under the Clean Water Act but there is no national, authoritative map for where these wetlands exist, which leads to controversies about the location of a wetland on a site, and the extent to which it must be conserved or may be developed. Wetland protection is understood in terms of defining the jurisdiction of the army Corps of Engineers rather than securing the functions or values of the wetlands themselves.

To accommodate development, wetlands were treated as identical and fungible and tradable. In other words, destruction of some wetlands was permitted if others were restored (the 'no net loss of wetlands' rule). This led to the establishment of a 'market' in wetlands mitigation projects. Further, wetlands are regulated primarily as an extension of managing dumping of solid waste into US waterways. Perfunctory nationwide permits are issued on an applicant's representation that it is not harming the wetlands in specified ways but there is little oversight and compliance is weak. Unfortunately, many states have not invested in their own rigorous wetlands systems (like New York) because of the federal law.

Wetlands (including peatlands) store large amounts of carbon and play an important role in stabilization of the climate. However, peatlands are not explicitly addressed in many national wetlands laws, and even in New York they are subsumed under wider wetlands classifications. The United Kingdom's National Committee for IUCN has developed a national program for Peatland Restoration. A part of its analysis documents the global warming potential of peat bogs. This program has demonstrated the success of re-wetting and restoring the ecological and hydrologic functions of the organic matter in, on and around peatlands. The UK National Committee shared its experiences with the 2012 IUCN World Conservation Congress in Jeju.

The commodification of the carbon cycle has resulted in fragmentation and trading of its parts while losing sight of the ecosystem. An exclusive focus on the carbon services of wetlands may result in loss of the wetlands as it is probably not going to create the capacity to adapt to sea level rise and the ensuing changes. It is imperative to stabilise the wetland system first and value it in perpetuity until external events wipe out the system. Then a compensation system is required to replace the lost part. He described this as a type of biotic insurance policy.

He concluded with the observation that each nation will come to cope with sea level rise, some sooner than others. The recent storm surges from Hurricane Sandy, which devastated parts of the New Jersey and New York coastlines, highlight the importance of adaptation. He cautioned that Singapore will have to construct wetlands, sand dunes etc. as buffers between the hardened coast and the dynamic sea -in order to avoid the recent events in the United States. 


\title{
A Survey of ASEAN Instruments on Peatlands, Mangroves and Other Wetlands: The REDD+ Context?
}

\author{
Emeritus Prof KL Koh \\ Director, Asia-Pacific Centre for Environmental Law \& Professor of Law, National University of \\ Singapore
}

Since the $13^{\text {th }}$ ASEAN Summit in November 2007, ASEAN has accelerated its response to climate change issues including REDD+ as a climate change mitigation and adaptation mechanism, besides providing opportunities for enhancing conservation and sustainable use of natural resources.

ASEAN plays an important role as a sub-regional organisation. It acts as a facilitator in the implementation of multilateral environmental agreements, such as the Ramsar Convention, the United Nations Framework Convention on Climate Change, the Kyoto Protocol, the Bonn Convention and the Convention on Biological Diversity (CBD), among others. The preamble to the ASEAN Declaration of Heritage Parks mentions the CBD and the World Heritage Convention (which includes natural sites). Although the Declaration does not explicitly mention the Ramsar Convention, some of the 30 Heritage Parks in ASEAN contain wetlands. ASEAN has also facilitated implementation through its various biodiversity strategies and plans of action contained in numerous instruments including the ASEAN Socio-Cultural Community (ASCC) Blueprint.

The other important role of ASEAN is to identify common issues among ASEAN countries and draft/ formulate plans of action/ strategies etc. to guide them. But there is no express mention of wetlands in the instruments/ documents of ASEAN countries.

There are many wetlands in ASEAN including more than 30 million hectares of peatlands accounting for 60 per cent of global tropical peatland resources that are of significance for carbon sequestration. They are also a major source of greenhouse gas emissions.

There are common issues and concerns among ASEAN Member Countries relating to peatlands such as transboundary fires (the 'Indonesian Haze'), loss of biodiversity, carbon losses, over-exploitation and drainage, etc. ASEAN attempts to address these issues through some key documents including the ASEAN Peatland Management Initiative 2003 and the ASEAN Peatland Management Strategy 2006-2020, which calls for national action plans to be aligned to its thrust and objectives.

The wetlands need to be examined in the context of two ASEAN documents - the ASEAN Common Position Paper on REDD 2008 and the ASEAN Common Position Paper on REDD+ 2010. ASEAN wants a cost-effective method of MRV so that communities themselves can manage the resources.

Prof Koh concluded her presentation by stating that on a broader perspective, one of the ways forward for ASEAN (and the world) is the adoption of a 'whole-landscape' approach for wetland use as a way to reducing emissions and carbon stocks in mangroves, peatlands and other wetlands that may not come within the ambit of REDD+ by including trees outside 'forests', wooded vegetation and other wetlands that may contain large carbon stocks. Otherwise the objectives of REDD+ will be compromised or hampered. 


\title{
Peatlands and Climate Change: the ASEAN GEF-IFAD Peatland Project
}

\author{
Dr Ramain Letchumanan \\ Head, Environment Division, ASEAN Secretariat
}

Dr Letchumanan commenced his presentation by emphasising the difference between peatlands (freshwater) and mangroves (salt water). He identified strong political will, financing because of genuine concern for conservation (and not for carbon credits) and robust methodologies as some of the essential factors for the success of REDD+.

Southeast Asia is home to 60 per cent of the global tropical peatlands (of which $50 \%$ is in Indonesia). The objective of the ASEAN Agreement on Transboundary Haze Pollution (Agreement) is to prevent and monitor transboundary haze pollution as a result of land and/ or forest fires.

The ASEAN Peatland Management Initiative 2003 was adopted by the ASEAN Member States to enhance peatland management in the region. Under this initiative, ASEAN Member States have developed the ASEAN Peatland Management Strategy (2006-2020) (Strategy) to guide actions to sustainably manage peatlands and reduce fires and associated haze within the framework of the Agreement. The ASEAN Environment Ministers endorsed the Strategy in November 2006. The Ministers also requested Senior Officials to pursue its implementation, particularly the finalisation of National Action Plans.

In order to support implementation, the ASEAN Secretariat and ASEAN Member States developed the Rehabilitation and Sustainable Management of Peatlands in Southeast Asia (ASEAN Peatland Forests Project (APFP)) with the assistance of the Global Environment Centre and funded by the Global Environment Facility through the International Fund for Agriculture Development (IFAD). The aim of the project is to demonstrate, implement and scale up sustainable management and rehabilitation of peatlands in ASEAN as part of the implementation of the Strategy. APFP involves work in pilot sites in four participating countries, namely Indonesia, Malaysia, Philippines and Vietnam. At the country level, actions have included development of a National Action Plan on Peatland, conservation, restoration and rehabilitation of peatlands, translation of the Strategy into local languages, peatland assessment, capacity building and awareness generation, e.g. through workshops for training of trainers, GIS trainings etc.

The regional component involves workshops, training programmes (e.g. for fire prediction and monitoring tools/ systems), publications, and outreach and technical support. The publications include the Roundtable on Sustainable Palm Oil's Manual on Best Management Practices for Existing Oil Palm Cultivation on Peat. APFP promotes cooperation with the plantation sector to prevent fires, good water management in existing plantations and simple and appropriate technologies for water retention in fields, e.g. by blocking abandoned drains in adjacent fields.

The project has been in full implementation since late 2010. Due to delay in initiation, its completion date has been extended by one year to June 2014. A mid-term review was undertaken in October-November 2012 to assess progress and future strategies.

He agreed with the view expressed earlier by Prof Robinson that protection of sites must precede conservation efforts. For example, the ASEAN Environment Ministers 
endorsed the nomination of U Minh Tuong National Park in Vietnam as an ASEAN Heritage Park in September 2012, which gives it another layer of protection.

He mentioned that while most of the ASEAN Member Countries have a National Action Plan on Peatlands (Thailand and Brunei are the exceptions), there is no similar national action plan for mangroves.

\section{Implementing REDD+ through a Private Sector Partnership in Kalimantan, Indonesian Borneo}

\section{Ms Dorothea Pio}

BioCarbon Coordinator and Biodiversity Specialist, Fauna \& Flora International

Ms Pio began her presentation by introducing her organisation, Fauna \& Flora International, which was founded in 1903 and currently operates in 40 countries. The aims of the organisation are: to prevent biodiversity loss without compromising human needs, to ensure the long-term sustainability of conservation and to influence the processes at the root of biodiversity loss.

Its partners include BioCarbon (Macquarie, Global Forest Partners LP and IFC - for provision of capital and financial services and marketing and sales of carbon credits globally), Yayasan Hutan Hijau (advisory body) and PT Wana Hijau Nusantara (Indonesian owned company engaging in forestry, conservation and trade).

Fauna \& Flora International (FFI) aims to develop model avoided deforestation projects, which will be verified both by the Verified Carbon Standard (VCS) and the Carbon Community and Biodiversity (CCB) standard. For this, the project has to satisfy certain criteria including compliance with government-established REDD framework, additionality, avoidance of leakage, deliver permanence, legal certainty over carbon rights, strong local community benefits, effective preservation of biodiversity and other ecosystem services and commercial viability and certification under appropriate carbon market standard.

She described an innovative REDD project being implemented by Fauna \& Flora International on 39,306 hectares of Danau Siawan Belida peat swamp forest in West Kalimantan, Indonesian Borneo in 2008. The forest faces significant pressure for clearance and conversion to palm oil. The objectives of the project are to prevent conversion of this forest to palm oil, to conserve the ecosystem and the threatened species it contains, and to improve community wellbeing. The proposed project protects the area surrounding the Ramsar-listed Danau Sentarum National Park. Her presentation reviewed the opportunities and challenges of the project after three years from inception with insights on the advantages and disadvantages of this financing model for REDD in Indonesia.

The feasibility assessment and project development is complete and project implementation is pending. The VCS validation of the project was completed in March 2012 (first FFI project to be VCS validated!) and the validation to the CCB standard should be completed in early 2013. But the domestic legal and regulatory framework and the attendant red tapism has slowed things down. Timeframes to get the license are often in conflict with investor needs and intense commercial pressure. 
The main challenges include lack of belief in REDD+ mechanism and the perception that there is insufficient commitment of developed countries to provide REDD+ incentives to developing countries. There is friction between central and provincial governments especially due to pressure from the latter on local political policy. Frustration with delays is another challenge. REDD is perceived as a waste of time (too many meetings and discussions!) and local government often opt for land-use which they perceive as providing real benefits to the community, e.g. mining and plantations. Finally, the government and the NGO community views NGOs who collaborate with the private sector with suspicion.

She then identified the features of a good private sector funded REDD project. Insofar as the host country is concerned, there should be low 'country risk' (in terms of voice and accountability, political stability, government effectiveness, regulatory quality, rule of law, control of corruption), it should be committed and involved in REDD (e.g. it could be a member of UN-REDD or the World Bank's Forest Carbon Partnership Facility or enter into a bilateral partnership), open to private sector investment (e.g. by making public statements in support of market-based carbon trading and/ or having a generally favorable investment environment) and having a high deforestation rate. The project location should be in a geographically defined area and of a large size. There should be legal, geographically registered linkage between carbon and land. Clear legal title may also be established through a Government carbon rights legal document.

She concluded her presentation by comparing privately funded projects with donorfunded projects. The former are more flexible and have the resources to obtain high quality data in surveys and assessments and to implement monitoring. On the other hand, in case of donor funded projects, significant revenues from carbon sales go to conservation and local communities (instead of the private sector investor), large carbon yields are not required to make the project financially viable, and the delivery of return on investment is not as urgent.

\section{Exploiting the Wetlands in the Anthropocene Epoch: The Structure and Development of the Argumentation}

\section{Ms Tiina Korvela}

\section{Doctoral Candidate, University of Helsinki, Finland}

Approximately one-third of the land area of Finland (i.e. more than nine million hectares) is wetlands or bogs. Approximately one-third of these wetlands are in their natural condition, i.e. undisturbed by human activities or in conservation areas. Historically, the remainder has been drained for agriculture and forestry but from the 1970s, the wetlands have been mainly used for peat production. Also, there are cultural reasons for the negative attitude towards wetlands due to the cold caused by them.

According to Ms Korvela, exploitation of wetlands for peat production is not considered mining in Finland. It is considered as an industry regulated by the Environmental Protection Act (permit requirement) as well as the Water Act.

Because peat production is a highly controversial issue and there is a division of opinions, it has not been possible to draft a separate legislation for its regulation (and preparations were cancelled in 1994). In her presentation, Ms Korvela considered the 
three different arguments used in the discourses around the exploitation of wetlands in Finland and how the legal regimes of wetlands have evolved.

(i) The sovereignty argument, which has been dominant for a long time, adopts a nationalist approach according to which a country can exploit its natural resources as it pleases. According to Ms Korvela, the argument is strongly anthropocentric as it emphasizes the nation's rights over its region, which is seen mainly as a source of natural resources. The forms of use exclude conservation and the focus is on forestry, agriculture etc. instead. The Parliament was more eager to have a separate statute on peat production than the committees preparing the regulation.

(ii) The no harm argument from international law has gained weight since the 1970s among conservationists. Some wetlands should be preserved; but the rest can be drained up and burnt. As in the case of the sovereignty argument, the Finnish Parliament was more in favor of the draft statute than the preparatory committees.

Courts have also played a proactive role in using the no harm argument. In the Area $\mathrm{K}$ case, which involved water quality issues resulting from humus produced as a result of peat burning, the object of regulation was not the wetland itself but the surrounding area, especially the surrounding waters and/ or lower reaches. Since the means of wetland protection is not available in environmental law, the Supreme Administrative Court used the European Union-based law for management of water resources instead since wetlands and water are connected. Similarly, when permission for peat production is sought, the Finnish Association for Nature Conservation (FANC) keeps local activists updated on the possibility of use of participatory rights, influencing the process and the appeal.

The Parliament was of the view that a separate statute could resolve the conflict between conservation and production. Ultimately, the differences in opinion were so severe that the draft was cancelled.

(iii) Insofar as the climate change argument is concerned, Ms Korvela highlighted that in Finland, peat is viewed as a 'slowly renewable energy source' and its devastating effect on climate change has been neglected. Recently climate change has emerged as an argument for wetland preservation in Finland. The draft National Climate Act mentions wetlands in the methods for improving the carbon balance and that the most efficient ways are to avoid ditching and to focus peat production on wetlands which are already ditched or which have otherwise lost their 'natural' condition. However, the complete shut down of peat production is not a topic being discussed in that context yet.

Further, climate change is not an argument in the national wetlands politics. For example, it is not even mentioned in the National Strategy for Mines and Peatlands (NSMW) 2011 which aims to provide thorough guidelines for wetlands usage. Ms Korvela concludes by stating that the climate change argument exists but it is vague and fragile.

Ms Korvela concluded her presentation by stating that there is some hope for the future of the Finnish wetlands. She highlighted the innovative interpretations of regional environmental authorities and the Supreme Administrative Court. They have used national strategies and river basin management plans drafted according to the obligations of the progressive EU Water Framework Directive instead of the conservative approach of the National Strategy for the Framework of the Water 
Pollution Control Until 2015. Further, since the climate change argument is fragile, the 'no harm' argument has been used for wetland preservation, as in the Area K case.

\section{REDD+ and Mangroves: A Study on Sundarbans}

\section{Mr Saifull Karim}

Associate Lecturer, Southern Cross University, Australia

Sundarbans, a Ramsar and World Heritage site, is the largest single block of tidal halophytic mangrove forest in the world covering parts of Bangladesh and India.

The Forest Department of Bangladesh has developed project design documents for a project called 'Collaborate REDD+ Improved Forest Management (IFM) Sundarbans Project (CRISP)' to save the only remaining natural mangrove forest of the country. The CRISP project involves conservation of 412,000 hectares of natural mangrove forests and is expected to generate total emission reductions of about 6.4 million tCO2e over a 30-year period.

A comprehensive legal and institutional review and reform is needed for successful implementation of the proposed CRISP project. The legal issues include land ownership (whether they are owned by the government and if yes, what are the livelihood rights of people in such forests), forest ownership and use rights, customary rights (e.g. of the Chittagong Hill Tribes), community-based forest rights and carbon rights.

The Asian Development Bank, in its Completion Report of the Sundarbans Biodiversity Conservation Project, cited 'weakness in its implementation arrangement' as the main reason for the poor performance of the project.

The success of a project will depend upon honouring legal rights of people and the ability of the project to make a change in the practical sense.

\section{Discussion}

It was clarified that while all six original ASEAN members have signed the 1985 ASEAN Agreement on Conservation of Natural Resources, only three have ratified it (Indonesia, Philippines and Thailand); therefore, it is not in force. The ASEAN Secretariat had a relook at the Agreement and it is agreed that it requires changes. Further, the Convention on Biological Diversity is more current than the Agreement. In this situation, whether amendments should be introduced before all five countries ratify the original Agreement has not been determined.

A comment was made that some of the provisions of the Agreement, such as the ones relating to protected areas, are useful for conservation. However, it should be noted that the Agreement was enacted in 1985 and is now dated.

Prof Robinson provided the historical background to the drafting of the Agreement. Its first draft was prepared by IUCN's Environmental Law Centre on the basis of the African Convention on Conservation and Natural Resources, which considered colonial treaties and earlier agreements, and modernised it in light of the Stockholm Convention in 1972. The Convention has been very successful in Africa and it has been revised twice to 
introduce advanced nature conservation standards. But it is not advisable to simply lift and adopt the template, which was prepared in Africa, in South East Asia. He suggested that it may be better to take some of the useful principles out of the Agreement and move them through the ASEAN administrative process perhaps as 'soft law'. Prof Koh added that the reason for non-ratification of the Agreement is that the original ASEAN countries did not claim ownership of the drafting of the Agreement. Further, the Agreement was framed by the people who were involved in the preparation of the Brundtland Report of 1987. So, forward-looking provisions were included in the Agreement, which were too advanced for ASEAN Member Countries to implement at that time.

Workshop participants highlighted the existence of different perceptions about what ought to be done as an issue. For example, there is difference of opinion between different government ministries as well as between central and provincial governments. In addition, the differences at the national level, there is lack of international consensus.

Mr Karim stated that it is very difficult to gauge the role of law in practice. There is great emphasis on mitigation in Bangladesh because it is very difficult to retreat from the coast. There are national adaptation policies etc. but if the 16 per cent area does get inundated, people have nowhere to go because other places are not available.

The problem of illegal logging as a barrier to implementation of REDD+ projects was identified and the need for monitoring was highlighted. For this purpose, it is important to start a dialogue among ASEAN members. For example, a company in Singapore is involved in tracking certification using DNA to determine whether logging is legal or illegal. However, DNA certification is not very common. It was pointed out that ASEAN Member Countries (e.g. Indonesia, Malaysia and Vietnam) that are exporting timber to the EU market are required to fulfil the certification requirement and/ or participate in FLEGt. But the problem is that most of the timber from South East Asia is being exported to China and Japan where similar certification requirements are absent.

In response to a question about leakage, it was clarified that Fauna \& Flora International's project in Indonesia went through the audit as a requirement of the VCS. There were no leakage sites in the areas around the proposed project site. The land is recognised as forest on state land listed for conversion to agriculture with recognition of some community rights. The Ecosystem Restoration License (ERL) will provide the commitment to change land use. There has been intense communication with the communities about benefit sharing over the past two years and there is strong community support. A minimum 20 per cent of total project revenues go directly to the community based on the existing regulation. It was recognised that negotiations with the provincial government will cause further delay. While the district-level government is fine, the provincial-level governor is not convinced because he thinks that palm oil and mining are better for the community. It is difficult to arrange meetings with the representatives of the provincial government, which leads to lack of communication. Lack of trust is another issue. It was suggested that as local people would also want to look at short-term returns, there should be a clear policy that provincial governments should look at long-term mechanisms. Ms Pio informed the participants that the connection between the central government and provincial government is tentative. The investors who operate in the voluntary carbon market are beginning to lose patience because the project started four years ago. 


\section{Theme IV: Case Studies of REDD+ in ASEAN}

\section{Moderator: Assoc Prof Lin-Heng Lye}

\section{The Progress on REDD+ Institutionalization in Indonesia}

\section{Dr Mas Achmad Santosa}

Deputy Head, Presidential Delivery Unit for Development Supervision and Oversight; Head of Working Group on Legislation Review and Law Enforcement, Presidential Task Force on REDD+ Indonesia

Indonesia is one of the ten most forest-rich countries; almost 70 per cent of the mainland is covered with more than 90 million hectares of forest. Among the main islands, the rate of deforestation is the highest in Kalimantan and the lowest in Jawa.

Mangroves were not popular in Indonesia until 2011 when the national government hosted a conference together with international organisations. In 2012, a Presidential Decree was issued to set up a coordinating team to prepare a national strategy to protect and manage mangroves.

In October 2009, Indonesia voluntarily committed to reducing emissions from the "business as usual" scenario in 2020: by 26 per cent with its own efforts and by 40 per cent with international efforts. The Government of Norway welcomed this commitment and agreed to sign a Letter of Intent on 26 May 2010 to pay USD 1 million to Indonesia based on verified emissions reduction and also to support Indonesia in preparing an agency for the implementation of REDD+ schemes.

This led to the issuance of Presidential Decree No. 19/2010 on Task Force for the preparation of REDD+ Agency. The outputs include: Draft of REDD+ National Strategy documents, Presidential Instruction No. 10/2011 on moratorium on new licenses and improvement of natural primary forest and peat land governance, and the preparation of Central Kalimantan as the first REDD+ pilot province in Indonesia. This Presidential Decree ended on 30 June 2011 and was continued by Presidential Decree No. 25/2011. The expected outputs include: establishment of new REDD+ Agency; MRV and funding instrument; improvements on forest governance including legislative reform, law enforcement and administrative procedures; and gazetting forest areas and consolidating licenses through legal audit and legal compliance or legal due diligence in the pilot province. This Presidential Decree will conclude in December 2012.

He then explained the three phases of the Letter of Intent (preparation, transformation and contributions for verified emissions) and the stages of development of the Presidential Task Force on REDD+.

The Presidential REDD+ Task Force includes members from ten different ministries and agencies including UKP-PPP, BAPPENAS, SKP, Sekretariat Kabinet, etc. The Chair of the Task Force oversees ten working teams, which are categorised into four clusters: Strategy and Planning, Institutional Building, Tactical Implementation and Overall Support, and are led by experts from government and non-government agencies.

The legal framework for REDD+ in Indonesia is made up of Presidential Regulations and the institutional arrangements comprise MRV, REDD + Agency and Funding Instrument. According to Dr Santosa, the REDD+ Agency should be established by January 2015. 
The National REDD+ Strategy document was released in 2012. It includes a National Action Plan on GHGs and the REDD+ Strategy (national and provincial). The first Provincial Strategy document was issued by the Governor of Central Kalimantan as regulated under the Governor Decision Letter No. 10 of 2012 (15 May 2012)).

He then discussed the President's Instruction No. 10/2011 regarding Moratorium on New Licenses and Improvement of Natural Primary Forest and Peat Land Governance, which involves suspension on new licenses issuance based on Indicative Map on New License Suspension (PIPIB), improvement of forest and peat land management governance, revisions on PIPIB every six months and application of moratorium for two years (2011-2013), which could be extended.

The creation of one indicative map has been challenging due to local/ regional autonomy issues, bureaucracy culture, corruption within bureaucracies and differences of methodology and definition causing different maps to be used by different ministries (for example, Environment and Forestry).

An inter-agency team headed by the Ministry of Forestry officials, of which the Presidential Task Force on REDD+ is a member, is developing the indicative map. Primary forests and peatland are included in PIPIB. While officers are not allowed to issue licenses for the areas in the indicative map for two years, an important question is what will happen after two years? According to Dr Santosa while this is up to the President, it is very important to use the two-year period to improve governance of the licenses and to prepare the enforcement officers for better performance. A major contribution of the process is that it has identified peatland (primary forest) in the area, and the indicative map can be accessed publicly.

During the discussion, Ms Khatirana clarified that areas in which licenses were issued before the Presidential Instruction are excluded to ensure legal certainty. The maps were issued in early 2011. Now the process is more rigorous - audits were conducted on some licenses and found that the licenses were not issued before the indicative map came into operation.

\section{The Status of REDD+ in Lao PDR}

\section{Dr Sithong Thongmanivong}

Associate Professor, Research Division, Faculty of Forestry, National University of Laos

Lao PDR (Laos) is a mountainous country, which depends on forests for sustenance. Hydropower plants in the mountains are the primary source of the energy needs of the country. The country has established a forest conservation management system for national, provincial, district and village forests but it has not been very effective. Deforestation and forest degradation continues in the country because of population growth, infrastructure development, timber exploitation and agri-business (including land lease and concession). The last of these causes, i.e. agri-business, is a recent development and involves use of degraded forests for agriculture. He clarified that there are no mangroves in Lao PDR while wetlands are converted to other uses.

Continuing deforestation and forest degradation are critical issues in Laos. In order to meet the National Forest Strategy 2020's target to increase national forest cover up to 70 per cent by 2020 (a level similar to the 1970s), the national government has 
designed and implemented a number of policies and programs over the past two decades. These initiatives include the national protected area system, the promotion of sustainable forestry management, and the implementation of land-use planning and shifting cultivation stabilization schemes. However, due to limited technical and financial capacity for implementation, these efforts for controlling forest encroachment and timber extraction had fairly limited success.

In Laos, REDD+ emerged as a relevant national policy issue in 2007. The government supports bilateral, multilateral and project-based initiatives and the involvement of multiple organizations and donors. The national government has expressed interest in the World Bank's Forest Carbon Partnership Facility (FCPF). Its Readiness Preparation Proposal (R-PP), which was submitted in 2010, was accepted in 2011 and the government is now awaiting financial support for implementation of FCPF.

A number of small- and medium-sized projects have been developed through bilateral cooperation such as the Climate Protection through Avoided Deforestation (CliPAD) project in two national conservation areas (Germany), the Participatory Land and Forest Management Project for Reducing Deforestation in Lao PDR (PAREDD) project in protected forest areas of Luang Prabang (Japan), the LEAF project (with the United States) and the SUFORD Program in national production forests (World Bank and Finland). These projects are currently testing and piloting REDD + activities in different parts of the country at the district and provincial levels.

Various international NGOs and the private sector are also involved or have expressed interest in developing REDD+ activities in the country. However, the government has been reluctant because of the lack of clarity regarding the international REDD+ framework.

The main activities in relation to REDD+ in Laos have focused on institutional and capacity building and the updating of forest and related legislation.

A new forest classification system is also being developed which considers land use and land cover types and the technical aspect of image processing capability for mapping and field monitoring. Currently, Laos does not have a REDD strategy or a MRV system. The national MRV system and most other technical strategies have been developed only in concept while institutional and ministerial rearrangements are underway. The R-PP is a roadmap policy document for Laos and it gives basic guidance for the development of MRV approaches. However, it leaves several technical and conceptual areas for further study.

The national government has decided to follow a nested approach for implementation of REDD+. REDD+ projects developed by private and/ or NGO actors will have to be included in sub-national jurisdictional REDD+ schemes. National strategies and institutional arrangements are being developed and related laws and regulations are being revised. The MRV system being developed by the government intends to capture performance of individual provinces and nested project-level activities into the national results. From there, two crediting pathways will be possible: project crediting and jurisdictional crediting.

A jurisdictional MRV system is considered more suitable for Laos than the accumulation of many individual projects. Although it will require a great deal of inputs in terms of infrastructural investment, technical assistance and capacity building at the sub- 
national level, it should lead to a more structured yet flexible context, allowing for the satisfaction of both national and external interests in REDD+ activity development.

The lessons learnt are that REDD+ implementation requires complex institutions and institutional mechanisms. In order to facilitate the building process, Laos has a strong interest in following emerging internationally recognised standards for jurisdictional, project-level accounting and social and environmental safeguards.

Pilot REDD+ projects have been initiated with international support. They are based in conservation areas and focus only on deforestation. There are very few benefits (it hinders local participation) and it is difficult to establish their additionality.

\title{
REDD+ in Philippines: Legal Status and Conservation of Mangrove Forests in the Philippines
}

\author{
Prof Gloria (Golly) Estenzo Ramos \\ University of Cebu, College of Law, Philippines \\ Ms Liza Osorio \\ Executive Director, Coastal Conservation and Education Foundation, Philippines
}

The Philippines is considered as 'the centre of the centre of marine biodiversity' in the world. 40 of the 54 mangrove species in the world are found here. Although it is a megabiodiversity country, it is also considered as the "hottest of the hot spots in species and habitat loss and destruction'. From an estimated 500,000 hectares of mangrove cover in 1918, only 120,000 hectares remained in the Philippines in 1994. The primary threats are habitat destruction and removal of mangrove areas for conversion to aquaculture, agriculture, urban and coastal development, and over-exploitation.

The Philippines has a wide range of freshwater or inland as well as marine and coastal wetland ecosystems. The major gaps in addressing the threats to coastal and marine wetlands include:

- Lack of comprehensive data to better understand the state of biodiversity of selected coastal and marine ecosystems

- Poor implementation of national policies and lack of national policies affecting the species and ecosystem diversity

- disparity in the capacity among government agencies and coastal municipalities in implementation of Integrated Coastal Management (ICM) plans

- Need for capacity building on ecotourism planning and management; adaptation to climate change

- Poor enforcement of coastal laws

- Lack of land-based livelihood projects to limit extraction

- Pervasive lack of appreciation of the services of wetlands

The Climate Change Act RA 7294, amended by RA 10174 in August 2012, harmonizes laws and policies related to climate change and disaster risk reduction and management. It gave broader powers to the Philippine Climate Change Commission. To prioritize the allocation and availability of funds for the implementation of climate related plans and programs, RA 10174 integrated Climate Finance and created the mechanisms for utilization of the People's Survival Fund. Under the latter fund, local 
governments are required to set aside 5 per cent (70 per cent of which will go towards capacity building etc. and 30 per cent for the occurrence of the actual contingency).

The Philippine National REDD-plus Strategy (PNRPS) lays the foundation for the eventual integration of REDD+ in the policies, programs and projects of the government and the stakeholders. It contemplates participatory planning and multi-stakeholder approaches among the strategies. The National Climate Change Framework and Action Plan integrate REDD+ and ecosystem valuation in decision-making.

The applicable laws on natural resources conservation include the Fisheries Code, the Forestry Reform Code, the National Integrated Protected Area System Act and the Wildlife Conservation and Protection Act. Some wetlands have a special law to govern their management, e.g. the Tubbataha Reef Natural Park in Palawan, but most have nothing. Further, there is no specific national law or policy on conservation and protection of mangroves, peatlands and wetlands in the Philippines. An exception is the National Wetlands Action Plan for the Philippines 2011-2016 (NWAP), which is intended to be the guiding document to promote and implement strategies and actions for the conservation and wise use of wetlands, incorporating urgent concerns such as biodiversity conservation and climate change mitigation and adaptation.

The other applicable regulations include executive orders issued under the Aquino administration. Executive Order No. 26 on the National Greening Program (NGP) requires planting of 1.5 billion trees covering around 1.5 million hectares for a six-year period (2011-2016) in certain areas. In order to address poverty issues, the NGP provides that all proceeds from agroforestry shall accrue to the NGP beneficiary communities. The latter are also considered a priority in the Conditional Cash Transfer (CCT) Program, which provides cash grants provided the beneficiaries comply with the NGP conditions.

Executive Order No. 23, 1 February 2011 declares a moratorium on cutting and harvesting of timber in natural and residual forests. However, the modalities still need to be worked out. Executive Order No. 79 of 2012 (or the new mining policy) declares certain areas (i.e. areas expressly mentioned in the mining law, protected areas, prime agricultural lands and tourism development areas) as no-go areas for mining. In other words, they are closed to mining applications for mineral contracts, concessions and agreements.

She then observed that the Philippines has the legal and policy framework to protect and conserve mangroves but they are scattered in different statutes and administrative regulations. Further, weak implementation of laws, overlapping of functions among agencies, and in general, poor management by the people and local governments have hindered the sustainable management of mangrove forests.

A REDD+ plan initiated by the civil society organisations is in the readiness stage. It focuses on capacity building of the government and people in the community to take ownership and to protect and conserve forests. It is expected to be scaled up in 2016 and implemented after that. It is hoped that the knowledge gap will be filled in the readiness stage and the Philippines will be prepared for its implementation, inter alia, by enacting the necessary laws and policies such as a national law for the conservation and protection of mangroves, peatlands and wetlands.

The National Strategic Plan on REDD+ recognises that REDD+ has the potential to motivate follow-through and policy implementation at multiple scales. For example, 
NGOs are partnering with private companies to implement REDD+ related projects in key biodiversity areas around the country. Prof Ramos shared the example of San Francisco in Cebu as a unique approach of empowering the community with the merger of top-down and bottom-up approach of governance. The municipality won the 2011 UN Sasakawa Award for Disaster Risk Reduction and Management for its pioneering, innovative and empowering San Fran Purok System of governance. However, even in this case, the challenges for REDD+ implementation are limited budget allocation, the absence of designated forest guards and the lack of technical expertise in carbon emission calculation.

Nevertheless, in her conclusion, she emphasised the importance of such collaborative approaches for implementation of REDD+ projects as the way forward.

\section{Asian Development Bank's REDD+ Related Work in the Greater Mekong Subregion}

\section{Mr Alastair Fraser}

Forestry Specialist, Greater Mekong Subregion Core Environment Program, Asian Development Bank, Thailand Resident Mission

Mr Fraser began his presentation by clarifying that ADB is not involved in any wetlands. He also clarified the difference between multilateral and bilateral donors, where the latter have a narrower approach. ADB, on the other hand, has a broader agenda based on what the country wants rather than what the donor wants.

The Core Environment Program and Biodiversity Conservation Initiative (CEP-BCI) is an initiative under the Greater Mekong Subregion (GMS) Economic Cooperation Program. The Environment Operations Centre of ADB was established to implement CEP-BCI under Regional Technical Assistance from ADB between 2006 and 2012.

CEP-BCI is a flagship regional project supporting biodiversity conservation and climate resilience across the GMS. During the pilot phase of the project (2006-2009), financial and technical assistance was provided to improve the livelihoods of communities within, or adjacent to, the corridor. A huge proportion of areas within the corridors are vulnerable to increasing development pressures and environmental degradation from the impact of Economic Development Corridors in Cambodia, Lao PDR, Thailand and Vietnam.

The concept of REDD+ was developing towards the end of the pilot phase. In the context of assessing sustainable sources of funding for forest conservation, the project commissioned two studies in Cambodia to assess carbon stocks and to determine whether such areas might be eligible for REDD+ funding.

In 2010, a regional investment project covering Cambodia, Lao PDR and Vietnam with total funding of USD 69 million was approved. The investments include delineation, demarcation and protection of forest areas, livelihood improvement and forest restoration and capacity building. The project planning phase recognised the possibility of including additional REDD+ funding especially in Lao PDR.

The Climate Change Fund, which was established by ADB in May 2008, provided Regional Technical Assistance grant for preparatory REDD+ work in Lao PDR, Thailand 
and Vietnam. The main purposes were to empower local communities to participate in REDD+ activities and to reduce transaction costs for future REDD+ funding. In Thailand, REDD+ capacity was built by supporting the development of national REDD+ plans. There was limited capacity to monitor, report and verify carbon benefits from potential REDD+ activities in Lao PDR and Vietnam. Therefore, the program defined potential interventions to pilot/ test participatory monitoring systems and to undertake Community-Based Carbon Stock Assessment and changes in stocks as a preliminary to preparing reference emissions levels for the Biodiversity Conservation Corridors.

Following a scoping study in 2009, ADB undertook a feasibility study for the establishment of a "carbon neutral" transport corridor in the GMS East-West Economic Corridor traversing Thailand, Lao PDR and Vietnam. The study assessed the technical and economic feasibility of reducing greenhouse gases (GHG) emissions from transport and offsetting through sequestration. It also studied the impact of the road corridor on forest cover in the buffer zone. The study has shown that there is scope for both improving fuel use efficiency and offsetting GHG emissions with increasing sequestration through restoration of forest cover within the corridor buffer zone. It also outlined potential pilot projects for subsequent phases of the program.

In 2010, Lao PDR was selected as a pilot country for the Forest Investment Program (FIP) to provide investment funds for piloting REDD+ activities. The FIP Investment Plan was approved in early 2012 and it includes additional funding through the BCC project in southern Lao PDR for innovative activities leading to reductions in GHG emissions. This component is currently in the preparation stage.

The second phase of the Core Environment Programme and Biodiversity Corridor Initiative (CEP-BCI Phase 2), which will continue till 2016, has a component covering climate resilience and low carbon strategies. This will complement the integrated landscape and ecosystem based approach by seeking co-benefits from the mitigation of forestry related emissions, both from reduced forest conversion and degradation as well as increased forest stocks.

In the next few years, the recently approved Phase II of the ADB Core Environment Program will continue and expand the work done so far in relation to REDD+. This program adopts an integrated landscape and ecosystem based approach and will seek co-benefits from reductions in forest GHG emissions as well as other forms of PES. ADB is also working with the World Bank to support the national government of Thailand in preparing a REDD+ Preparation Proposal for submission to the FCPF, especially stakeholder consultations.

\title{
The Trials and Tribulations of Developing REDD+ Legislation in Indonesia
}

\author{
Dr Laode M Syarif \\ Faculty of Law, Hasanuddin University, Indonesia \& Partnership for Governance Reform in \\ Indonesia
}

Dr Syarif began his presentation by citing the Indonesian President's strong commitment to reduce absolute greenhouse gas emissions by 26-41\% by 2020 (without or with foreign help) as an important factor for the initiation of a number of REDD+ 
demonstration activities and pilot projects across Indonesia. However, the absence of an adequate legal framework to develop and manage these activities and projects puts them at risk in the future.

The Environmental Protection and Management Act (EPMA) has climate change provisions concerning mitigation and adaptation. The most relevant law for REDD+ is Law No. 41/1999 on Forestry, which relates to all forest activities. In the eyes of the Ministry of Forestry, REDD is their domain. But the provisions in the forestry law are outdated.

He identified the existing horizontal and vertical inconsistency between different levels of government (central, provincial and district) as well as different sectoral legislation (forestry, environment, energy and mineral resources, finance, agriculture etc.) as one of the major challenges. Corruption or the big $\mathrm{C}$ is another major problem. In Indonesia, it is not the absence of laws but the poor implementation of existing laws that presents an obstacle due to, for example competition between government agencies Environment v. Forestry v. Office of the Presidential Unit for Overseeing. The insufficiency of, and inconsistency between, existing laws on issues such as tenurial rights, which are critical for REDD+ projects, is a major shortcoming of the legal framework.

Dr Syarif clarified that most of the regulations that are relevant for REDD+ projects are not in the form of legislation but are crafted by the Executive as regulations, decrees or instructions from the President. The Executive, especially the Ministry of Forestry, has issued 'specific' ministerial regulations to manage REDD+ projects in Indonesia. For example, Ministerial Regulation No. P.36/Menhut-II/2009 on Procedures for Business Licensing for Carbon Sequestration and/ or Storage in Forest Production and Protected Areas is for the voluntary market projects. Further, these instruments are insufficient, do not have substantial legal impact and some of their provisions contradict other laws such as agrarian law, spatial planning law, local autonomy law and financial balance law between central and regional government. Inconsistency (with laws that have a higher standing) also creates implementation problems.

The office of the President has also initiated several policies and legislation that aim to regulate or at least attempt to provide policy and legal foundation for REDD+ projects in Indonesia. The REDD+ National Strategy and the Presidential Decrees No. 19/2010 and 25/2011 on the Task Force of the Preparation for REDD+ Institution have direct implications. Others such as the Presidential Instruction No. 10/2010 on the Moratorium for the New Concession and Improvement of Forest Management on Primary Forest and Peatland, which prohibits new forest concessions, will assist in implementation of REDD+ projects.

The Executive has issued all of these policies and regulations without any consultation with the Parliament. It may be argued that involving the Parliament may lead to more politicking. So, basically, there is no REDD law in Indonesia at the moment. 


\title{
Extending REDD+ to Mangroves and Wetlands for Small Island States $\&$ Conservation of Mangroves and Inter-tidal Mudflats in Singapore
}

\author{
Vinayak Dharmarajah \\ Nature Society, Singapore \\ Assoc Prof Lye Lin-Heng \\ Faculty of Law, National University of Singapore
}

Mr Dharmarajah's presentation examined the suitability of wetlands as REDD+ projects in small island states (SIS). He first discussed the implementation of REDD+ to mangroves and the relevance of small island states, which are unlikely to have large areas of inland forest cover and need mangroves to mitigate storm surges. As mentioned by Dr Friess, mangroves and mudflats contain a higher amount of carbon than terrestrial forests. It is therefore in the interest of SIS to maintain mangroves. In order to maximise the benefits of maintaining mangroves (on small tracts of land), proper land use planning should be followed to derive substantial carbon revenues.

There are a number of challenges for the application of REDD+ to mangroves including an understanding of the underlying mechanisms that control carbon sequestration in the ecosystem, difficulties in rapid and accurate measurement of MRV of below ground carbon, changes in natural ecosystems and the amount of carbon they sequester, and externalities and processes that have an impact on the viability of a site.

He then discussed the role of law in relation to management and enhancement of mudflats and mangroves as assets. According to Mr Dharmarajah, law should (i) regulate human activities that encourage sediment outflow such as human induced wave erosion, removal of mud (for reclamation, dredging and construction of coastal fortifications), land-based encroachments and unrestricted human activity on mudflats, (ii) ensure that sediment inflow is not impeded inter alia by building dams, causeways and other coastal fortifications, (iii) ensure that mangrove cover is not lost by deforestation, changes in wave energy and changes in water content, (iv) formalise legal arrangements in relation to enhancement of these assets by strategic replanting of mangroves and recreation of mudflats, and (v) encourage better scientific understanding of the relationship between carbon sequestration and mangroves and the application of MRV procedures in relation to mangroves and mudflats.

The conservation of mudflats and mangroves can also be advanced from a biodiversity conservation standpoint. The requirements include ensuring pollution-free sites, habitat connectivity, water quality, protection of related species, protection from invasive alien invasive species, and reduction in noise and air pollution. Further, poaching and collection of inter-tidal species should be prevented and human activity and movement on mudflats should be limited.

Singapore is not a party to the Ramsar Convention and it is unclear if it would satisfy the criteria for identifying wetlands of international importance. However, according to $\mathrm{Mr}$ Dharmarajah, the 'wise use' of wetlands criteria should be adopted by Singapore. In order to adopt the Ramsar approach, the first step is to identify and assess the effectiveness of existing legal and institutional measures for the promotion of wetland conservation and wise use, analyse how sectoral and institutional measures affect wetlands, directly or indirectly, and critically evaluate the processes or activities that adversely affect wetlands. 
He then suggested guidelines for framing of laws for the wise use and conservation of mangroves and mudflats. Given the dynamic nature of marine areas, a holistic and strategic approach, which addresses the externalities and processes beyond the site, is necessary. This will require an integrated coastal management strategy/ policy, spatial, land and coastal planning and a marine environment use and protection strategy.

It is also necessary to develop new administrative structures (such as a national scientific and management body and an inter-departmental authority for mangroves and mudflats) and laws (such as a coastal management law or code of practice) for environmental governance. The introduction of a law mandating Environmental Impact Assessment/ studies is required to minimize (and anticipate) the impact of threatening processes on the integrity of carbon stocks and habitats given the dynamic nature of the marine systems. The law should adopt a broad perspective on environmental impact.

Transboundary cooperation is essential to protect carbon stocks and species. For example, Singapore and Johor authorities should initiate talks to protect their wetlands through collaboration and coordination. The Ramsar Convention promotes international cooperation but while Malaysia is a party to it, Singapore is not.

The law must also address land and water usage issues that may have an impact on the viability of mudflats and mangroves. Land use regulations must define permitted and prohibited activities on mudflats. Coastal development adjacent to mudflats may be permitted subject to certain restrictive covenants. Concessions may be granted to academic institutions/ NGOs for mudflat conservation or site-management agreements may be entered into for this purpose. Owners of property near mudflats may be granted tax incentives for sustainable management of mudflats. Laws should address the impact of shipping on coasts and biodiversity.

Mitigation and offsetting should be made legal requirements. The law should create inter-tidal protected areas that address the specific threats faced in relation to carbon sequestration and inter-tidal species. It must address all threats of habitat connectivity and promote the protection/ conservation of inter-tidal ecosystems as well as nearby terrestrial ecosystems and related and adjoining coastal/ inter-tidal sites. Where it is not possible to designate specific mangroves and mudflats as protected areas, law should create other land-use categories, e.g. areas of scientific and educational interest, to offer a more limited form of protection. Periodic threat assessment of coastal biodiversity should also be carried out.

Assoc Prof Lye's presentation examined the issue of protection of wetlands in the citystate of Singapore. She stated that the structure, context and mechanism of REDD+ projects does not quite fit in the case of Singapore, a highly urbanised country. However, she added that the benefits of keeping forests and ecosystems intact apply equally to developed and developing countries.

Singapore has one legally protected wetland site - the Sungei Buloh Wetlands Reserve, which was gazetted as a nature reserve and recognised as a site of international importance for migratory birds in 2002 and became Singapore's first ASEAN Heritage Park in 2003. In June 2010, a Master Plan was launched for its expansion to encompass at least three other mangroves, reservoirs and marshes in the nearby Lim Chu Kang and 
Kranji areas. A part of the reserve will become a 'restricted access area to protect its biodiversity' and (easily available) special permits will be needed for access.

The existing laws in Singapore include the Parks and Trees Act, which provides protection to flora and fauna in these parks and reserves. Penalties for breach include a fine (up to SGD 50,000) and/ or imprisonment (up to six months). In addition, the Foreshores Act, the Fisheries Act, the State Land Encroachment Act, the Environmental Public Health Act and the Wild Animals and Birds Act (WABA) deal with various aspects of environmental management and protection in inter-tidal areas outside the nature reserve. It is unclear whether WABA protects fish, reptiles or invertebrates. There are no laws to protect marine areas except the Foreshores Act, which prohibits taking of corals, and the Fisheries Act, which prohibits use of poisons, explosives or trawl nets, and keeping of or release of piranhas into the waters.

Singapore is a party to the Convention on Biological Diversity (CBD), which provides the legal basis to expand the protection of mangroves and mudflats in Singapore. The CBD also has an EIA provision but Singapore does not have an EIA law. The existing risk assessment regulations are narrow and only relate to pollution. A number of ASEAN instruments also promote/ foster conservation and sustainable management of coastal and marine ecosystems/ habitats. The importance of integrated coastal management was recognised in the 2009 PEMSEA Declaration. Other relevant instruments and documents include the voluntary East Asian Australasian Flyway Partnership Agreement, motions adopted at the 2012 IUCN World Conservation Congress and the IUCN Situation Analysis on East and Southeast Asian intertidal habitats.

Singapore should enhance existing laws to address more specifically the challenges and threats faced in conserving mangroves, mudflats and inter-tidal ecosystems, and facilitate their conservation and rehabilitation. She proposed that the legal protection extended to Sungei Buloh should be expanded to encompass the mudflats at Kranji, which is home to the Asian horseshoe crab, and the mangroves of Mandai. It should also be aligned with inter-tidal and coastal management strategies advanced under the auspices of the Ramsar Convention on Wetlands of International Importance, and the CBD. She also noted the passing of two motions at the recent IUCN World Congress, on the conservation of the Asian horseshoe crab and the protection of the East AsianAustralasian Flyway. This Flyway supports more migratory water bird species and a higher proportion that are globally threatened than any other flyway in the world, and Singapore is part of this partnership.

Although Singapore is not a party to the Ramsar Convention, Assoc Prof Lye drew attention to the fact that the Tanjong Piai site in the state of Johor is a Ramsar site. As a new port is being developed in the estuary of Tanjong Piai, it may be included in the Montreaux Record of the Ramsar Convention, which lists all Ramsar sites where changes in ecological character have occurred, are occurring or are likely to occur. Further, a part of Singapore (Sungei Buloh reserve) should be viewed ecologically as an extension of the Tanjong Piai site in the state of Johor, Malaysia. This will require a collaborative arrangement between the two governments and the enactment of relevant laws, which is subject to the resolution of several transnational issues and political and economic sensitivities. Assoc Prof Lye expressed the hope that greater appreciation of the benefits of wetlands conservation (vis-a-vis economic development as well as climate change) would make this possible in the future. 


\section{Discussion}

REDD+ has the opportunity to act as a catalyst for governance reforms. The participants highlighted the importance of capacity building to improve participation. A reference was made to the cooperation with UNDP-Indonesia where data is used for participatory governance. This improves the capacity of the government, the community and businesses. Data and regulatory framework can also be improved.

In the context of Indonesia, the need for a two-way approach was highlighted: assist the government from inside and create pressure from outside. It was noted that there are exceptions but it was observed that there is still a long way to go before this can be replicated - especially at the district level.

In response to a question whether the issue was technical capacity or institutional capacity insofar as remote sensing is concerned, Dr Thongmanivong stated that it was institutional capacity (both funding and manpower issues) because GIS centres last only so long as there is a project. He gave the example of a JICA project, which proposed to establish a national information centre for Lao PDR. But this national focus is restrictive because the local government cannot benefit from such institutional capacity building. Mr Fraser also observed that most of the GMS countries have some GIS capacity imagery is relatively readily available. The problem, according to him, is that at least four of the five GMS countries have split responsibilities for forestry among different ministries. As a result, data/ information is split and they conduct inventories/ monitoring on their own. He also highlighted the difficulty of obtaining good, comprehensive national data. Further, there is a general tendency in the country not to know the situation especially at the higher level in order to avoid subsequent blame.

Associate Prof Lye observed that the best laws cannot work in the absence of the right policies, institutions and implementation. It is important to be smart about foreign aid and to draft and enact appropriate laws and engage in capacity building.

Gazetting and land title were identified as major problems in Indonesia. In response to a question as to whether the Indonesian Ministry of Forestry's carbon sequestration regulation has been successful in preventing logging, it was clarified that although this law was crafted to fulfil the standard of 'good regulation', this is not enough.

In response to a question about who decides how much to give to the community, it was observed that the Indonesian forestry regulation is inadequate. Benefit sharing depends on different actors - those operating on the ground, the local government etc. Usually the regulations are silent on benefit sharing aspect, which contradicts the transparency requirement but the absence of a solid legal basis is an impediment. It is also difficult to determine which 'community' should receive the 20 per cent share.

About the system of distribution of the money (USD 1 billion) coming from Norway, $\mathrm{Dr}$ Syarif and Ms Khatarina clarified that the Letter of Intent states that money will be released if Indonesia performs certain actions. As all money in Indonesia is in the form of grants, it does not directly go to the Ministry of Finance. Instead, it is managed by a third party - the UNDP in the case of money from Norway (because of corruption concerns etc. and it is audited by both international and government auditors). Other aid is managed by the National Development Agency, which maintains a list for this purpose. It was observed that Norway's main worry is what will happen post 2014 (when the Indonesian presidential elections take place) because the REDD Task Force 
has been established by the current President and the UKP-PPP. In the absence of a law establishing these institutions, there is uncertainty about their continuance post-2014.

A question was raised about the definition of 'forest' in the context of REDD+ and how far it falls within the context of the national definition. The discussion revealed that ASEAN Member States have adopted different definitions of the term 'forest'. Many ASEAN countries follow the FAO definition (10 per cent canopy cover). But Vietnam has 30 per cent canopy cover. In Indonesia, the terms 'forest' as well as 'forest area' are defined. Malaysia argues that if they follow the Kyoto Protocol definition, all of Malaysia is a forest, because plantations are included. Therefore, the participants agreed that there was no need for harmonisation of forest definitions within ASEAN in accordance with the definition of 'forest' under the Kyoto Protocol because the latter is so defined for a particular purpose. Further, national sovereignty necessitates respect for national definitions of forests.

\section{Theme V: Investments in REDD+}

\section{Moderator: Prof Nicholas A Robinson}

\section{REDD+ and the Current State of the Market: A Role for Singapore?}

\section{Mr Ralph Strebel \\ Carbon Conservation Pte. Ltd., Singapore}

Mr Strebel first gave a brief introduction of the REDD+ projects in which his organisation, Carbon Conservation Pte. Ltd., is involved. These include the first CCBAapproved REDD project in the Ulu Masen Ecosystem in Aceh, Indonesia, which is a 750,000 hectare forest. The project was verified by the Rainforest Alliance. Carbon Conservation Pte. Ltd. also partnered with Asia Pulp \& Paper Co. Ltd. (APP) to develop the Kampar Carbon Reserve, the world's first privately funded REDD-type project, on 15,640 hectares of peat forest on the Kampar peninsula in Sumatra.

He relied on the Ecosystem Marketplace's State of the Forest Carbon Markets 2012 to understand trends and forecasts for forest carbon markets globally. Its importance lies in the increasing prominence of forest projects in international climate action strategies. The trends show that forest carbon markets continue to move forward although they make up a small part of the overall carbon market. The overall value of forest carbon markets in 2011 was USD 237 million. The value of credits increased 33 per cent since 2010 - the market wide average price was USD 9.2/tCO2e, which is double of USD 5.6/tCO2e in 2010 - but transaction values decreased by 22 per cent. Although many projects were looking to come online, they did not actually do so.

A review of the historical transaction volumes by market indicates a reduction in 2011 (compared with 2010). However, voluntary carbon standards have maintained their market lead. Most credits are voluntary credits being produced through the VCS and the California system. The private sector was the primary supplier of credits in the carbon market.

The contracted credit volumes from A/R projects (most of which were initiated at least five years ago) have increased dramatically. According to Mr Strebel, the A/R share is expected to increase in 2012 but it will not be as much as the voluntary carbon market. 
On the other hand, the volume of REDD credit transactions fell by 62 per cent due to complexities and costs of new methodologies, decreased demand from European buyers and intricacies of tenure, community building and evolving policy environments. But the downturn in the REDD market is temporary. A clear market signal and capacity building, among other factors, should turn the market around.

The largest volume of credits was contracted from Latin American countries. The market share of North America and Africa has increased and 97 per cent of the credits from Africa were sold to EU buyers. There was a drop in volumes in Asia but significant developments have been reported on the ground. The volume from projects in Australia and New Zealand received a boost as developers began preparing for the Australian carbon pricing mechanism.

There are 18 REDD VCS projects to date out of which five are in Asia and one, the Rimba Raya Biodiversity Reserve Project, is in Indonesia. It was validated but it never produced credits as it ran into political problems.

VCS dominates the market share for standards followed by CDM. There is a variation in project types (mostly small Plan Vivo projects with low transaction costs) and standards (including self-produced in-house standards from University of Edinburgh). Mr Strebel observed that voluntary credits are being purchased mostly for CSR purposes.

The landscape of the forest carbon market is evolving as different types of actors and project approaches are entering the mix. However, developers continue to struggle to find new sources of offset demand in international voluntary markets. The year 2012 witnessed some efforts to reignite interest through campaigns such as the Code-REDD campaign to raise awareness among corporates about the critical need for REDD.

The decline in market transaction volumes was mainly due to the decline in the voluntary markets. New methodologies are just coming on stream and there is a global price pressure. The reason for the low prices of certified emissions reductions is that the first commitment period under the Kyoto comes to an end in 2012 and people are rushing to the market with their credits. As a result, many carbon shops are closing. It is a difficult time for the overall carbon market even though the forest carbon market is increasing in size. This shows that the carbon market is still not a panacea, as was originally envisaged.

Insofar as the role of Singapore is concerned, it should update its international position and become a REDD supporter and leader. The government can provide financial support to other ASEAN Member Countries, direct investment into regional SFM activities and continue support to carbon and REDD+ start-ups. Singapore can provide technical capacity in the form of GHG management systems training, enhance research in earth science with a climate change focus and support regional technical capacity assessment.

Singapore can contribute to the enhancement of legal capacity by training personnel and distributing knowledge in order to develop clear definitions of key terms such as forest, wetlands, etc. and to legalize carbon trading with indicators for the involvement of the private sector. GHG management issues can be incorporated into the course curriculum of universities and polytechnics in order to prepare a new breed of well- 
trained individuals. A regional MRV training hub can also be established to impart methodology and accounting training.

\section{REDD+ and CDM: A Comparative Perspective}

\section{Lovleen Bhullar}

Law Researcher, Environmental Law Research Society, New Delhi

Several features of the REDD+ mechanism are the subject matter of ongoing discussions at the national level. One of these issues is whether REDD+ should be included within the existing international climate change law and policy framework, completely separate or form part of the Clean Development Mechanism (CDM). Ms Bhullar's presentation focused on examining the similarities and differences between REDD+ and CDM.

For this purpose, she first explained CDM as envisaged under the international climate change law framework, that is, the United Nations Framework Convention on Climate Change (UNFCCC) and Article 12 of the Kyoto Protocol. She then explained how COP7 led to the inclusion of Afforestation/Reforestation (A/R) CDM activities within this framework. While afforestation involves establishment of forests in areas not forested for at least 50 years, reforestation involves the establishment of forests in areas deforested before 1990. However, natural forestry-based projects were excluded. A/R CDM activities were also subjected to more procedural restrictions than other CDM projects. For example, Annex I countries could not offset more than one percent of their annual baseline emissions with the credits generated. Further, the A/R CDM project credits could not be included in the European Union (EU) Emissions Trading Scheme (ETS). This constrained any potential demand from the ETS regulated companies.

The features of many A/R CDM projects include: they are on private or communal land, stakeholders or the community are involved, they are developed by international NGOs or state agencies along with community groups and they are funded by NGOs, state agencies or investors. These projects are of a particular size, range and type and they usually do not account for divergent local conditions.

Ms Bhullar then contrasted A/R CDM projects and REDD+ projects. While the CDM projects focus on afforestation and reforestation only, the objectives of REDD+ projects include Reducing Emissions from Deforestation and Degradation (REDD) + sustainable forest management + enhancement of carbon stocks. Further, while the distribution of $\mathrm{A} / \mathrm{R}$ CDM projects is unevenly skewed in favor of certain developing countries, REDD+ projects are most likely to be undertaken in least developed countries or the less developed parts of developing countries. The A/R CDM projects follow a project-based approach. On the other hand, REDD+ projects can take place at different geographical scales. However, the different scales (that is, national, sub-national and hybrid) have their own advantages and disadvantages. For example, REDD+ projects at the national level allow the pursuit of a broad set of policies and create domestic ownership. At the same time, given the widespread governance failures in many developing countries, such projects may not be feasible in many countries. It is also more difficult to mobilise private sector or local government involvement in such projects.

She also highlighted certain common issues that both CDM and REDD+ have to address. These include the problems of leakage, additionality and permanence. However, she 
emphasised that depending on the geographical scale at which REDD+ projects are carried out, the impacts of these problems may be more severe. Both of these carbon mitigation mechanisms must also address financial issues, capacity concerns, complexity of projects and how to ensure effective stakeholder participation. The last of these issues is of particular significance in the context of REDD+ where the interests of forest-dependent individuals/communities must also be taken into account. Here, ownership and benefit sharing are two of the main issues.

In her conclusion, Ms Bhullar emphasised the need for flexibility in the implementation of the REDD+ mechanism because different countries have different conditions and capabilities. She also highlighted the importance of involving the local community and partnerships with organisations having technical and financial capacity. Finally, in her view, some trade-offs are inevitable: for example, some leakage is unavoidable and legitimacy and effectiveness may not be achieved in equal measures. In other words, REDD+ is one of the mechanisms (like CDM) for carbon mitigation; it is not the only mechanism.

\section{REDD+ Investments: The Experience of Carbon Conservation}

\section{Mr Ralph Strebel \\ Carbon Conservation Pte. Ltd., Singapore}

Mr Strebel's organisation has been focusing most of its recent efforts on sustainable forest management (SFM) projects. Project investors and developers face a number of risks in the South East Asia region. The absence of a clear market signal from the international policymakers is an important policy risk. Among technical risks, while REDD+ methodologies have matured, they are less supportive of the ' + '. Leakage is also a major issue. What about companies that want to expand SFM activities? Further, the leading REDD+ countries continue not to have strong legal underpinnings. In order to address legal risks, top-down government is better than devolution but laws are required to support title for carbon credits and integration of relevant laws in the country is also necessary.

Insofar as financial risks are concerned, money is tight, overseas development assistance (ODA) money is not really flowing towards such projects and private investors are not interested as they are more REDD savvy than before. Private sector is driven by efficiencies and is responsible to the board and the bottom line. Therefore, it is essential to secure finance before starting a REDD+ activity and to pool to spread risk across different projects and to partly address the permanence issue.

A major political risk is that expectations have been poorly managed by governments, which change along with positions regarding REDD+. One risk management strategy is to maintain good relations with the government.

Carbon Conservation Pte. Ltd. is involved in seven REDD+ projects in three continents covering 1.2 million hectares of forest. The Ulu Masen REDD+ project in Aceh, Indonesia, which covers an area of 3.25 million hectares, is the first CCBA validated REDD+ project in the world. In 2007, the Governor of Aceh committed to 'no logging'. Carbon Conservation partnered with Fauna \& Flora International and the Provincial Government of Aceh for this project. Funding for VCS validation was acquired in 2010 
but the project is held up because of lack of internal capacity of the province. There is disagreement between the central government and the provincial government. The initial lack of methodology has also slowed down progress. The change in provincial government has resulted in the project being put 'under review'.

Similarly, the project feasibility assessment for the Kampar Carbon Reserve project in the Riau Province of Indonesia has been completed and the approved VCS methodology is available. However, the project is on hold due to lack of financing options in the post GEC landscape.

Financing for the District of Lebong REDD+ project in Sumatra, Indonesia was secured through a reputable European utility off-taker who were keen to invest a portion of their carbon portfolio into a solid REDD project that demonstrated biodiversity and community benefits. But the project is on hold due to a change in government.

Another project, the North Pikounda REDD+ project, is a VCS voluntary project designed to protect 92,530 hectares of a forest area of unlogged native Congolese forest. The project was formalised in May 2012. The forest management plan formed the baseline report for the project.

The success of a forest carbon project depends on robust scientific knowledge, transparency, use of a conservative principle for calculation, best practices, recognised standards and credible partners.

Mr Strebel concluded his presentation by stating that although REDD+ is tricky, we should stick with it as we have attained substantial knowledge and experience. Future REDD+ projects may have an Improved Forest Management - Logged to Protected Forest (IFM-LtPF) and/ or timber component.

\section{Discussion}

The decrease in REDD+ transactions cannot lead to the conclusion that there is less interest in REDD+. At present, there are 19 validated projects but only 4-5 are producing credits. Others will start producing credits over the next few years. Further, the REDD pipeline is bigger than A/R CDM projects. Governments, such as the Singapore government, can provide the financing in some cases.

In response to a question about the possibility of corrupt behavior in the Congolese context, $\mathrm{Mr}$ Strebel clarified that the Congo baseline report is actually a forest management plan and it is one component. Auditors will want to see normal rates of harvesting for the rest of the concession. In order to avoid corruption, one can also work with a FSC-certified company.

In the Ulu Masen project, Carbon Conservation Pte. Ltd. approached the Governor as an individual rather than cooperating with the government. This is a function of the politics of time where you need to work with someone who can get things done. The Ulu Masen project was the pet project of the Governor but there was no broad support and no budget because Aceh could not receive capacity development funds from ADB as it is not a government and the provincial 'government' has a tenuous relationship with the central government.

It may be difficult to count government effort as a REDD project because investors are not interested if they cannot own the credits. However, there can be a revenue sharing 
model, e.g. imposition of land tax, per tonnage tax, etc. The permanence issue has another dimension: while change in government is an issue, it is also possible that the market may lose interest in REDD+ projects in the future. In order to ensure that REDD+ is not as complicated as CDM at the project level, methodologies are being simplified. Further, it is important to use a conservative principle.

\section{Theme VI: Tackling REDD+ Issues and Drafting Legal Framework}

\section{Moderator: Mr Vinayagan Dharmarajah}

\section{Law and Policy on Peatlands: The Indonesian Experience}

Ms Josi Khatarina

Working Group Legal Review and Law Enforcement, Satgas REDD+, Indonesia

Ms Khatarina's presentation discussed Indonesia's current efforts to ensure sustainable use of peatland in the context of REDD+. She first laid down the current condition of Indonesian peatland, which accounts for 21 million hectares of the country's total land area of 183 million hectares (83 per cent of the peatlands in South East Asia). But there are a number of pressures on peatlands: land clearing, deforestation, oil palm plantation, agriculture, slash and burn and canalization.

She then elaborated on the policy options that are considered to be a priority to rectify and improve the situation. In the National Action Plan on Climate Change 2007 (RANPI), the action plans relating to peatlands include prevention of forest fires through implementation of the National Action Plan to Prevent Forest Fires and the National Strategy on Sustainable Peatland Management. Peatlands are also covered in the National Action Plan to Reduce Greenhouse Gases 2011 (RAN-GRK). The envisaged activities include rehabilitation, reclamation and revitalization of degraded and abandoned peatland on agricultural land. The National Strategy on REDD+ 2012 also includes several action plans relating to peatlands.

The legal framework on peatland comprises among others the Ramsar Convention (at the international level), which has been adopted into national legal framework; at the national level, some laws are directly related to peatland, for example, national laws relating to spatial planning, environment, forestry and plantations; there is also an upcoming law (a draft of Government Regulation) on swamps and peatlands, which is in the final stage of the legislation process. At the policy level there are, among others, presidential instructions on peatland rehabilitation in Central Kalimantan and on moratorium.

(i) The new Indonesian environmental law requires a spatial plan based on ecoregion at island level. The spatial plan is an important instrument to classify the function of peatland in production or protection areas. The spatial planning law prescribes that a violation of the spatial plan is a crime, which may be committed by the perpetrator as well as the issuer of the license. 14 out of 34 provinces have finalised their Provincial Spatial Plan (which should have been done in 2009). The approval of the forest area presents a major challenge in the finalization of the spatial plan. 
(ii) It is important to reclassify peatland with high carbon storage that is in the area of production into protected areas. However, the current criteria for protected areas does not include carbon considerations. The upcoming government regulation on peatland, which seeks to expand protection areas and foster enforcement, may address the issue. Further, the Presidential Decree 10/11 on Moratorium requires one moratorium map of new licenses on primary forests and peatlands (of any thickness). The moratorium map will involve reclassification of some areas. Carbon may be included if the moratorium map is integrated into the spatial plan. The confusion among forest officers can be removed by expediting gazettement of forest area.

(iii) The binding Guidance on the Utilization of Peatland for Oil Palm 2009 imposes a strict requirement on the utilization of peatlands and provides technical guidelines for water management on peatland, among others. However, there is no such limitation for forest plantations and therefore EIA cannot be used for this purpose. The forthcoming government regulation on swamps (which includes all types of wetlands including peatland) should provide a stronger legal basis for water management on peatland. This regulation is different from the upcoming government regulation on mangroves because it only deals with water management of the area; not conservation.

(iv) The forthcoming government regulation is silent about accelerating the establishment of a Peatland Management Unit (KPH) (a body similar to Forest Management Unit but for peatland).

(v) There is a need to prepare a mechanism and legal framework to enable land reclassification for peatland (which involves shifting unprotected lands to protected lands) followed by land swap mechanism. Land swap should be backed up by reclassification of protected areas and be preceded by license registration and review with focus on licenses in peatland areas. But there is no legal obligation relating to license registration and review in Indonesia except in the case of the Central Kalimantan project. The recently amended Government Regulation No. 10/2010 regulates land swaps on production forest but not in the context of peatlands.

(vi) Insofar as reduction of hotspots is concerned, the forestry law and plantation law impose severe criminal sanctions for slash-and-burn practices including license revocation. The upcoming government regulation on swamps is likely to play a crucial role in water management.

(vii) With regard to promotion of peat rehabilitation, the Environmental Act stipulates steps of rehabilitation in general and recovery of environmental damages as part of administrative and criminal sanctions. The upcoming Government Regulation on Peatland will also play a crucial role in rehabilitation. In this context, she also cited one example of a rehabilitation project where the conversion of peatlands into a one million hectares mega rice project in Central Kalimantan was stopped in 1999. This was followed by a Presidential Instruction laying down a plan of action to conduct rehabilitation in the area.

(vii) The strengthening of enforcement of crimes on forest areas through environmental courts ("green benches") and integrated and better coordination between the police and prosecutors should be backed up by stronger criminal laws. In Indonesia, burning, illegal use of peatland and its utilization that causes environmental damage are crimes. The Supreme Court has established a green bench, the ministries of forestry and environment have set up an integrated law enforcement team and Act No. 
$32 / 2009$ stipulates that the civil investigator can bring the cases directly to the prosecutor (and not through the police, as was the case earlier). But there is lack of administrative enforcement. However, she gave the example of the case of Rawa Tripa, which was reported to Satgas REDD+ by Walhi Indonesia. In this case, Walhi also brought objections through the Administrative Court and based on a decision of the Administrative Court, the extension of a company's license was revoked by the Governor of Aceh. Criminal and civil law proceedings are going on against companies that are suspected of committing slash-and-burn activities in their area.

Ms Khatarina concluded her presentation by stating that while there are many action plans on the table for sustainable management of peatlands, they need to be solidified and concretized, e.g. by making them part of the operational plan for development, i.e. the Long-Term and Mid-Term National Development Plan. Harmonization of existing laws and policies (and institutional support) is required for their effective implementation. The upcoming laws are expected to give clearer direction and better institutional support to sustainable management of peatlands. Enforcement of laws is still very weak and it is important to strengthen the role of civil society in this process.

\section{Managing Risks of Using REDD+ to Manage Rich Socio-ecological Systems}

\section{Prof Paull Martin}

Australian Centre for Agriculture and Law, University of New England, Australia

There are two distinct mindsets in commerce - (i) the innovator and entrepreneur, which dominates the 'naive enthusiasm' stage of the development of markets and (ii) the risk manager, which emerges from experience that early optimism needs to be tempered with a concern for risk. According to Prof Martin, risk is the 'ying' to opportunity's 'yang'. He asked whether it is possible to minimise the hazards of naivety in REDD+?

Payment for Ecological Services (PES) schemes include a great variety of 'business models' (including payments for anticipatory services). PES have proven to be most useful where there is an alignment of the values and interests of powerful economic interests with the interests of protection of the environment, for example, in the form of payment for protection of watershed services, which have included water quality, fish stocks, flood mitigation and landscape values.

However, while PES successes are touted, the reality of risk and the potential costs of failure are concealed, as is the case with market instruments generally. Less desirable outcomes tend to arise where the interests are more complex or the interests of the supplier and the buyer are less aligned, or where the governance systems are not well developed. According to Prof Martin, the governance of REDD+, which is a uniquely complex form of transnational PES, needs to pay greater attention to the risks of policy failure. This is because REDD+ is intended to be a multi-billion dollar market (high economic value) with a high social impact on less powerful people, and therefore there is a substantial risk that dominant economic interests will override less powerful social interests. 
There is a risks problem embedded in the concept of REDD+ itself. It potentially violates several market theories about the use of markets for the efficient management of a resource' thus suggesting significant policy risks that need to be governed.

The goal of REDD+ is to shift social systems and to sustain ecological systems. There are three readily identified categories of 'policy risk' which could impede the achievement of this ambitious goal.

The first category is political risks which include the potential for political frustration of the policy intent and the potential for agency and community frustration of implementation of that policy. Among these risks is the potential for corruption, or the creation of markets and governance arrangements to achieve private interests without due regard to the interests of the public.

The second category of risk is instrumental failures that can arise from causes such as fragmented strategies being pursued by poorly implemented instruments. Instrumental failures can plague both markets and public regulation and the results can be outcomes that are insufficient, costly and unfair. The transaction complexities of the various REDD+ initiatives suggest a substantial potential for instrumental inefficiencies that may impede the development of a viable market.

Spillover risks are unanticipated impacts on vulnerable interests (e.g. marginalised people or species). They include:

(a) Environmental spillover risks. PES partially price ecological systems, which means that all values of that system are not 'valued', and unpriced interests remain vulnerable. Environmental markets attach an economic price to only some attributes of a natural system (generally those that are readily measured and appropriated in some tangible form) and thereby increase attention to conserving or increasing that service value. But, by implication, other values (e.g. of the micro-environment that are non-appropriable or fugitive) remain un-valued by the market and may in fact be more likely to suffer depreciation as economic attention increases on only some aspects of the natural system. This creates a complex relationship between technical issues of valuation and measurement and the risks of relative depreciation and accelerated loss of some values that are not 'marketised'.

(b) Social spillover risks, particularly to the weak in society. Through markets, resources are shifted to the economically competent, but this implies a shift from the less economically competent in all market arrangements. There may also be risks of economic distortion such as 'hidden' subsidies in market arrangements and secondary impacts on other resource users. Some of the commentary on environmental markets including REDD+ suggests that this is a common impact of the use of markets for environmental values in developing economies. Further, there are intrinsic risks with monetisation, as this leads to partial pricing of total systems and might contribute to 'crowding out' of non-funded stewardship. Beneficial policies and institutions can be undermined as a result of the governance effects of 'property-ising' and the proliferation of complexity and transaction costs.

(c) Economic spillover risks, which are a possible result of the competitive impact on 'adjacent' industries. This risk is pronounced when the affected industries are small scale and dispersed, with no powerful advocates for their support (such as subsistence users of forests). 
From observation of the way in which REDD+ is being developed, it seems that no one is in-charge of risk governance and no one is thinking, in a carefully structured way, about what could go wrong and what should be done to avoid or manage the risks. This leads Prof Martin to the unfortunate conclusion that insofar as REDD+ is concerned, the standards of risk governance are poor when compared to the standards of risk assessment of major strategic projects in the private sector.

The desire for success of REDD+ should not result in minimisation of attention to the very real risks. On the contrary, it is the strongest possible reason for taking a careful approach to risk management. As implementation comes closer, efforts to identify and propose risk management actions in REDD+ are intensifying. But these efforts are not integrated programmatically nor have the necessary institutional power. Prof Martin highlighted the need to establish a high quality risk management team that is able to address the 'big picture' architectural hazards and the more detailed implementation risks.

\title{
Discussion
}

It was agreed that it is important to learn from successes and failures. But who is learning and what are they learning? Do we have a system for continuous improvement from our mistakes as well as our successes? Also, are potential problems being consciously anticipated? At present, new rules are being created to plug problems as they emerge, but this does not seem sufficient to ensure success. An integrated community of practitioners (rather than perhaps a research institute) who have different perspectives, is likely to be the most suitable approach to identify issues and draw lessons from them. One problem is the absence of transparency about the implementation experience of REDD+. Developing countries are in part unwilling to share information because of distrust of private companies - sharing of knowledge might lead to a more efficient accumulation of experience and solutions. This highlights the need to create a knowledge-sharing platform.

\section{Fostering REDD+ Investment through Effective Legal Frameworks: Lessons from the Development of Early Forest Carbon Projects}

\author{
Dr Sophie May Chapman \\ Research Fellow, Department of Land Economy, University of Cambridge \\ Martijn Wilder \\ Partner, Baker \& McKenzie
}

Private sector participation in financing the implementation of the REDD+ mechanism was recognised at the Conference of Parties to the United Nations Framework Convention on Climate Change held in Durban. However, the exact details of the REDD+ mechanism (including generation of tradable carbon credits) are still being debated. In other words, REDD+ readiness has been delayed.

At the same time, the voluntary market has emerged as a major driver of REDD+ investment and it has facilitated the development of numerous REDD+ projects. The experiences in the voluntary projects provide an insight into the practical challenges for REDD+ implementation. These include defining, securing and allocating rights to 
carbon, ensuring the permanence of REDD+ areas, and creating 'investment-grade' carbon commodities, which are capable of attracting private sector finance.

Public sector finances are insufficient to scale-up REDD+ implementation and private sector participation is required. However, it is possible to use public money during the initial phase (for capacity building to reduce transaction costs) to leverage private finance later (which makes REDD+ more attractive to investors).

In order to incentivise private sector involvement, facilitative legal frameworks for REDD+ are imperative. After highlighting the general/ practical issues for REDD+ project design - baselines and additionality, leakage, permanence, and community and biodiversity benefits, the presentation focused on the major legal challenges concerning investors in REDD+ project development from a project-level, private sector perspective.

A clear formal approval process must be laid down in a formal domestic legal/ regulatory framework in order to reduce transaction costs, delays etc. It is also necessary to clarify rights to land ownership and use as it has a bearing on successful project implementation (and permanence); as a starting point for determining carbon tenure (i.e. who owns the rights to the carbon, and carbon credits); protecting indigenous and community rights under REDD+; and gender equality. Dr Chapman emphasised that in REDD+ (unlike CDM), the interests of local stakeholders cannot be ignored because they determine the viability and credibility of the REDD+ project. She gave the example of a project in Kenya where carbon finance was used to leverage other sustainable activities.

In this context, Mr Strebel clarified that while the Voluntary Carbon Standard is surprisingly weak on the community aspect, the CCBA standard is very subjective but it takes biodiversity and community benefits into account. However, it is expensive and it is not a strong standard. For investors, validation is enough, which is based largely on project design document. But CCBA wants verification, i.e. confirmation that the project design document has been implemented, before issuing credits, which would happen at least one year later. To the best of their knowledge, there is no verified CCBA.

The right to benefit from the forest carbon stored within the boundaries of the land (carbon tenure) must also be established. As carbon has become another natural resource, the entitlement to REDD + credits may be derived from statutory provisions, local laws, customary rights and private contractual arrangements.

The general project-related issues for a commercial REDD+ project include project structuring in accordance with broader host country domestic law requirements and structuring and implementation requirements that may be imposed under an international REDD+ framework. For example, foreign entities are not permitted to own land in Indonesia and therefore they must find a local partner. It is also necessary to ensure that local communities who may now face reduced rights or access to the forest receive an equitable share of the benefits generated from the protection of the forest as a REDD+ project. This will promote their involvement in and acceptance of the projects as local stakeholders, which will facilitate successful project implementation. A trust account or fund may be set up for benefit sharing.

The decision to invest in a REDD+ activity is largely influenced by the anticipated returns. In this regard, the specific project-level issues related to mangroves, peatlands and other wetlands include their carbon sequestration potential and the location and 
socio-economic context. Laws pertaining to the use of waterways and the status of protected areas will also be relevant to the project design. The ownership and use rights of these ecosystems may overlap or be unclear. The tenure arrangements are also relevant for establishing project activities, securing permanence of credits generated and community engagement.

In her conclusion, she restated the lessons from the existing voluntary projects for policymakers and future project proponents and the features of domestic legal frameworks that support standards that deliver real, permanent, additional and verified mitigation outcomes. She also highlighted the importance of project-specific circumstances in the specific case of mangroves, peatlands and other wetlands.

\section{Discussion}

The issue of tenure rights and carbon rights is crucial for REDD+. In Malaysia, title to property means ownership of above and below the land. If there are minerals on the property, the owner is taxed by the government. Can a similar issue arise in the case of REDD+? In response, Mr Strebel stated that outside of projects undertaken by Carbon Conservation Pte. Ltd. in Australia, there are no privately owned lands. For example, APP does not own the land - they are concessionaires and have a right to the product from the land and sometimes they can be excluded from the non-timber forest products. In Indonesia, the state owns the entire forest - the lessee receives rights to the products of the forest. For example, Indonesian law P36 in 2009 allowed concessionaires to access carbon.

In response to a question about the manner in which soil rights (containing the carbon) were transferred in the Kenyan REDD+ project, it was clarified that ownership of carbon was deemed to be transferred with ownership of the land. This highlights the importance of the government's determination of whether carbon is a natural resource or a fruit of the land. The issue of declining carbon rights also needs to be addressed but it does not receive adequate attention at present.

\section{THEME VII: Concluding Remarks}

Prof Koh thanked the presenters for raising critical issues for the development, implementation and monitoring of REDD+ as a carbon governance mechanism. One of the important issues is the need to develop legal capacity in the ASEAN region and other parts of the world. A concern was raised that instead of focusing on mangroves, peatlands and other wetlands, the workshop had paid significant attention to the general issues. In this context, Prof Robinson highlighted the importance of duality, i.e. the need to understand the problem as well as find solutions. As mangroves, peatlands and wetlands are critical in the cycle of mitigation, it is important to identify, conserve them and qualify them for REDD+ projects.

A comment was made that the Ramsar Convention on Wetlands ought to have received a boost following the importance gained by the climate change issue but that has not happened. While peatlands are on the agenda in the context of adaptation, at present, there is only one REDD project that includes peatlands. This does not mean that peatlands are not on the radar; people are struggling to find an appropriate entry point for their inclusion. 
It is, therefore, imperative to facilitate the development of an appropriate legal framework and to build the capacity of countries in the ASEAN region and the world so that the internationally agreed-upon REDD+ framework can be effectively implemented and monitored. The workshop participants agreed in principle to contribute to the development of research and training programmes in the region for this purpose. 


\section{Day ONE - Thursday, 15 November 2012}

\section{OPENING CEREMONY}
8:30 am - 9:00 am
Registration
9:00 am - 9:10 am
Welcome Remarks
Dean, Law Faculty, NUS
9:10 am - 9:20 am
Remarks by Ms Evelyn Khoo, Director (Policy \& Planning), NCCS

THEME I. SETTING THE STAGE: OVERVIEW OF GENERAL ISSUES RELATING TO REDD+: ASEAN AND THE WORLD

Objectives: To set the stage and scope the subsequent discussions to focus on gaps related to REDD+ and legal frameworks for mangroves and peatlands.

\section{Moderator: Emeritus Prof KL Koh}

9:20 am - 10:00 am Introductory Panel (Prof NA Robinson; Mr Ralph Strebel, Ms Tiina Korvela, Prof Paul Martin, Dr Laode M Syarif, Dr Dan Friess)

10:00 am - 10:15 am C Coffee Break

\section{THEME II: SCIENTIFIC, ECONOMIC AND POLICY CONSIDERATIONS}

Objectives: To provide the scientific and economic background of mangroves, peatlands and other wetlands and its implications to policy

\section{Moderator: Ms Lovleen Bhullar}

$10: 15$ am $-10: 45$ am

Tropical Wetlands and REDD+: Unique Scientific Challenges for Policy

(Dr Dan Friess, Assistant Professor, Department of Geography, National University of Singapore)

$10: 45$ am - 11:15 am

The Economics of Mangrove Biodiversity and Ecosystem Services in Relation to Climate Change

(Dr Filliberto A Pollisco, ASEAN Centre for Biodiversity) 


\section{THEME III: ASEAN AND THE WORLD: MANGROVES, PEATLANDS AND OTHER WETLANDS}

Objectives: To highlight (i) the potential of REDD+ in enhancing mangrove and peatland conservation/ management, and (ii) key learning points from experiences in ASEAN and the world on mangrove/peatland conservation and (iii) identify gaps in ASEAN.

Moderator: Assoc Prof LH Lye

11:15 am-11:45 am Mangroves, Peatlands and Other Wetlands: Global Cooperation among National Programmes

(Prof NA Robinson, Gilbert \& Sarah Kerlin Distinguished Professor of Environmental Law, Co-Director, Center for Environment Legal Studies, Pace University School of Law USA)

11:45 pm - 12:05 pm A Survey of ASEAN Instruments on Peatlands, Mangroves and Other Wetlands: The REDD + Context?

(Emeritus Prof KL Koh, Director of APCEL \& Prof of Law, National University of Singapore)

12:05 pm-12:35 pm Peatlands and Climate Change: The ASEAN GEF-IFAD Peatland Project

(Dr Raman Letchumanan, Head, Environment Division, ASEAN Secretariat)

$12: 35 \mathrm{pm}-1: 00 \mathrm{pm}$

Implementing REDD+ through a Private Sector Partnership in Kalimantan, Indonesian Borneo

(Ms Dorothea Pio, Fauna \& Flora International)

1:00 pm - 2:00 pm $\quad$ Lunch Break

2:00 pm-2:30 pm Exploiting the Wetlands in the Anthropocene Epoch: The Structure and Development of the Argumentation

(Ms Tiina Korvela, Doctoral Candidate, LL.M., University of Helsinki, Finland)

$2: 30 \mathrm{pm}-2: 45 \mathrm{pm}$

REDD+ and Mangroves: A Study on Sundarbans

(Mr Saiful Karim, Associate Lecturer, Southern Cross University, Australia)

2:45 pm - 3:30 pm Discussion of Themes I, II and III

3:30 pm- 4:00 pm $\quad$ Coffee Break 


\section{THEME IV. CASE STUDIES OF REDD+ IN ASEAN}

Objectives: To understand progress in ASEAN countries in becoming REDD-ready and identify specific gaps to be addressed

\section{Moderator: Assoc Prof LH Lye}

$4: 00 \mathrm{pm}-4: 25 \mathrm{pm}$

$4: 25 \mathrm{pm}-4: 50 \mathrm{pm}$

$4: 50 \mathrm{pm}-5: 20 \mathrm{pm}$

$5: 20 \mathrm{pm}-5: 50 \mathrm{pm}$

$5: 50 \mathrm{pm}-6: 10 \mathrm{pm}$
The Progress on REDD+ Institutionalization in Indonesia (Dr Mas Santosa, Deputy Head, Presidential Delivery Unit for Development Supervision and Oversight; Head of Working Group on Legislation Review and Law Enforcement, Presidential Task Force on REDD+, Indonesia)

The Status of REDD+ in Lao PDR

(Dr Sithong Thongmanivong, Associate Professor, Research Division, Faculty of Forestry, National University of Laos)

REDD+ in Philippines: Legal Status and Conservation of Mangrove Forests in the Philippines

(Prof Gloria (Golly) Estenzo Ramos, University of Cebu, College of Law, Philippines)

Asian Development Bank's REDD+ Related work in the Greater Mekong Subregion

(Mr Alastair Fraser, Forestry Specialist, Greater Mekong Subregion Core Environment Program, Asian Development Bank, Thailand Resident Mission)

Discussion

\section{Day TWO - Friday, 16 November 2012}

\section{THEME IV. (CONTINUED) CASE STUDIES OF REDD + IN ASEAN}

\section{Moderator: Emeritus Prof KL Koh}

9:00 am - 9:20 am

The Trials and Tribulations of Developing REDD+ Legislation in Indonesia

(Dr Laode M Syarif, Law Faculty, Hasanuddin University, Indonesia \& Partnership for Governance Reform in Indonesia)

9:20 am - 9:40 am

Extending REDD+ to Mangroves and Wetlands for Small Island States \& Conservation of Mangroves and Inter-tidal Mudflats in Singapore 
(Mr Vinayagan Dharmarajah, Nature Society \& Associate Prof Lye Lin-Heng, Deputy Director, APCEL, Faculty of Law, National University of Singapore)

9:40 am - 10:30 am Discussion

10:30 am - 11:00 am Coffee Break

THEME V. INVESTMENTS IN REDD+

Objectives: To provide an overview of financial mechanisms for REDD+ (including comparisons with CDM) and highlight potential role of Singapore in REDD+ finance

\section{Moderator: Professor NA Robinson}

11:00 am-11:30 am REDD+ and the Current State of the Market: A Role for Singapore?

(Mr Ralph Strebel, VP of REDD+ / Senior Counsel, Carbon Conservation, Singapore)

11:30 am-12:00 noon $\quad$ REDD+ and CDM: A Comparative Perspective (Ms Lovleen Bhullar, Environmental Law Research Society (ELRS), New Delhi)

12:00 noon-12:30 pm REDD+ Investments: The Experience of Carbon Conservation

(Mr Ralph Strebel, VP of REDD+ / Senior Counsel, Carbon Conservation, Singapore)

12:30 pm - 1:00 pm Discussion

1:00 pm - 2:00 pm $\quad$ Lunch

\section{THEME VI. TACKLING REDD + ISSUES, AND DRAFTING LEGAL FRAMEWORK}

Objectives: To highlight aspects that should be included in any REDD+ legal framework and core capabilities needed in any country implementing REDD+

\section{Moderator: Mr Vinayagan Dharmarajah}

2:00 pm - 2:30 pm Law and Policy on Peatlands: The Indonesian Experience (Ms Josi Khatarina, Working Group Legal Review and Law Enforcement, Satgas REDD+, Indonesia)

2:30 pm-3:00 pm Managing Risks of Using REDD+ to Manage Rich Socioecological Systems 
(Prof Paul Martin, Director, Australian Centre for Agriculture and Law, School of Law, University of New England, Australia)

$3: 00 \mathrm{pm}-3: 30 \mathrm{pm}$

Discussion

$3: 30 \mathrm{pm}-4: 00 \mathrm{pm}$

Coffee Break

4:00 pm - 4:30 pm

Fostering REDD + Investments Through Effective Legal Frameworks: Lessons from the Development of Early Forest Carbon Projects

(Dr Sophie May Chapman, Research Fellow, Department of Land Economy, University of Cambridge)

4:30 pm - 5:00 pm Discussion

THEME VII. CONCLUSIONS

Moderator: Emeritus Prof KL Koh

5:00 pm - 5:45 pm Discussion and Round-Up of Day One and Day Two, and Future Work

5:45 pm - 6:00 pm Presentation of Tokens of Appreciation to Speakers (Water Colour Paintings by Marcus Lim)

6:00 pm - 7:30 pm Closing Reception 


\section{List of Invited Guests}

(in alphabetical order)

1. Dr Stephen BROWNE

Director of Operations, Asia-Pacific \&

Manager, Fauna \& Flora International

(Singapore) Ltd.

354 Tanglin Road

Tanglin International Centre

\#01-15, Tanglin Block

Singapore 247672

2. Ms Huilin CHIN

Senior Officer, International Organisations

Programme Office

Economic Development Board

250 North Bridge Rd

\#28-00 Raffles City Tower

Singapore

3. Ms Audrey HUANG

Executive

Mitigation \& Resilience Policy \& Planning

National Climate Change Secretariat

55 Newton Road

\#13-04/05 Revenue House

Singapore 307987

4. Mr Hassan IBRAHIM

Manager, Biodiversity/Terrestrial

National Parks Board

Singapore Botanic Gardens

House 6, 1 Cluny Road

Singapore 259569

5. Ms Xi Zhen KEUNG

Executive

Mitigation \& Resilience Policy \& Planning

National Climate Change Secretariat

55 Newton Road

\#13-04/05 Revenue House

Singapore 307987

11. Mr Desmond TAY

Deputy Director

Mitigation \& Resilience Policy \& Planning

National Climate Change Secretariat

55 Newton Road

\#13-04/05 Revenue House

Singapore 307987
6. Mr Benjamin LEE

National Parks Board

Singapore Botanic Gardens

House 6, 1 Cluny Road

Singapore 259569

7. Mr Hock Keong LUA

Manager

Biodiversity (Terrestrial)

National Parks Board

Singapore Botanic Gardens

House 6, 1 Cluny Road

Singapore 259569

8. Ms Youna LYONS

Senior Research Fellow

Centre for International Law

National University of Singapore

Bukit Timah Campus

Block B, \#02-01

469 Bukit Timah Road

Singapore 259776

9. Ms Valerie PHANG

Graduate Student

Department of Biological Sciences

National University of Singapore

10. Ms Becky RUSH

Asia Flyway Policy Officer

Birdlife International

354 Tanglin Road

\#01-16/17, Tanglin International

Centre

Singapore 247672

12. Mr Renshao XU

Executive

International Relations

National Environment Agency

Environment Building

40 Scotts Road

Singapore 


\section{ABOUT THE ASIA-PACIFIC CENTRE FOR ENVIRONMENTAL LAW (APCEL)}

Established in February 1996 by the Faculty of Law, National University of Singapore, at the initiative of the Faculty and the World Conservation Union - Commission on Environmental Law (IUCN-CEL), and in collaboration with the United Nations Environment Programme (UNEP), APCEL was launched on 1 July of the same year. The initiative was in response to the call in Agenda 21 to build capacity in environmental law and to promote awareness of environmental issues. APCEL has established itself as a centre of excellence in the region for capacity-building in environmental law, and is highly regarded worldwide.

The main objectives of APCEL are:

- To serve as a regional training centre for the teaching of environmental law;

- To organise conferences, seminars and other programmes on environmental issues;

- To serve as a regional centre for research, including multi-disciplinary research on international, regional and national environmental law and policy;

- To promote the exchange of information on international, regional and national environmental law and policy;

- To cooperate and collaborate with law schools, institutes, centres and such other organizations to further its objectives.

APCEL collaborates with many international, regional and local institutions in developing capacity-building courses in environmental law and management....

APCEL's activities also include the organization of various conferences on cutting-edge issues such as sustainable development of coastal and ocean areas in Southeast Asia, trade and environment, intellectual property rights and biological resources, and crucial issues in climate change and the Kyoto Protocol. 